University of Vermont

UVM ScholarWorks

2010

\title{
Chemical Composition and Nutrient Profile of the Low Molecular Weight Fraction of Bovine Colostrum
}

\author{
Scott Christiansen
}

University of Vermont

Follow this and additional works at: https://scholarworks.uvm.edu/graddis

\section{Recommended Citation}

Christiansen, Scott, "Chemical Composition and Nutrient Profile of the Low Molecular Weight Fraction of Bovine Colostrum" (2010). Graduate College Dissertations and Theses. 46.

https://scholarworks.uvm.edu/graddis/46

This Thesis is brought to you for free and open access by the Dissertations and Theses at UVM ScholarWorks. It has been accepted for inclusion in Graduate College Dissertations and Theses by an authorized administrator of UVM ScholarWorks. For more information, please contact scholarworks@uvm.edu. 


\title{
CHEMICAL COMPOSITION AND NUTRIENT PROFILE OF THE LOW MOLECULAR WEIGHT FRACTION OF BOVINE COLOSTRUM
}

\begin{abstract}
A Thesis Presented
by

Scott Christiansen

to

The Faculty of the Graduate College

of

The University of Vermont

In Partial Fulfillment of the Requirements

for the Degree of Master of Science Specializing in Nutrition and Food Sciences
\end{abstract}

May, 2010 
Accepted by the Faculty of the Graduate College, The University of Vermont, in partial fulfillment of the requirements for the degree of Master of Science, specializing in Nutrition and Food Sciences.

Thesis Examination Committee:

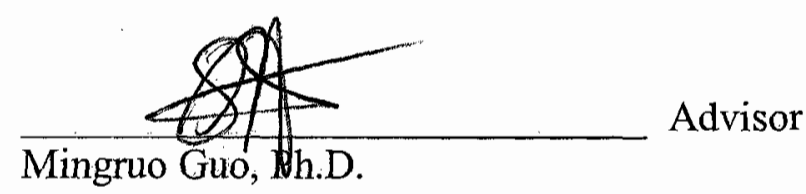

Cactimen: W. Qmelly

Catherine Wright Donnelly, Ph.D.

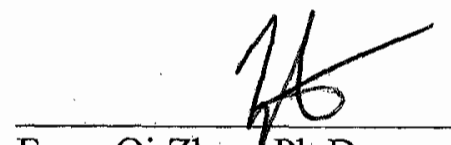

Chairperson

Feng-Qi Zhao/Ph.D.

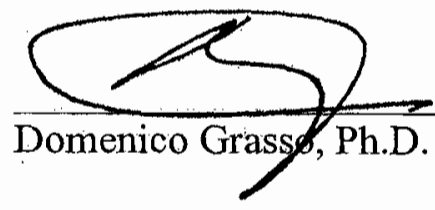

Dean, Graduate College

Date: March 11, 2010 


\begin{abstract}
Bovine colostrum collected within $12 \mathrm{~h}$ of parturition was de-fatted, de-caseinated, and ultrafiltered (UF) using a $5 \mathrm{kDa}$ cut-off membrane; the resulting UF permeate was freeze dried to create a powder with possible use as a functional food ingredient. Samples representative of five lots of this powdered "colostrum low molecular weight fraction" (CLMWF) were analyzed for chemical composition and nutrient profile. The average contents of fat, moisture, and ash were $0.6 \%, 1.7 \%$, and $8.3 \% \mathrm{w} / \mathrm{w}$, respectively. Carbohydrate analysis showed an average of $58.2 \% \mathrm{w} / \mathrm{w}$ lactose monohydrate with no monosaccharides, other disaccharides, trioses, or tetroses detected. The total nitrogen content averaged $1.13 \% \mathrm{w} / \mathrm{w}$, with $74 \%$ of this in the non-protein nitrogen fraction, producing a true protein content of $1.9 \% \mathrm{w} / \mathrm{w}$. A significant mass fraction of the material $(\sim 29 \% \mathrm{w} / \mathrm{w})$ remains to be characterized. The CLMWF powders were found to contain significant quantities of the minerals calcium (average $870 \mathrm{mg} / 100 \mathrm{~g}$ ), magnesium, (311 $\mathrm{mg} / 100 \mathrm{~g})$, phosphorus (1473 mg/100g), potassium (1705 mg/100g) and sodium (690 $\mathrm{mg} / 100 \mathrm{~g}$ ), the nutrients taurine (average $26.5 \mathrm{mg} / 100 \mathrm{~g}$ ), L-carnitine $(40.5 \mathrm{mg} / 100 \mathrm{~g}$ ), thiamine $(648 \mathrm{mcg} / 100 \mathrm{~g})$ and riboflavin $(6991 \mathrm{mcg} / 100 \mathrm{~g})$, and the nucleos(t)ides uridine $(55.2 \mathrm{mg} / 100 \mathrm{~g})$ and 5'UMP $(18.8 \mathrm{mg} / 100 \mathrm{~g})$, cytidine $(3.33 \mathrm{mg} / 100 \mathrm{~g})$ and 5'CMP (4.83 $\mathrm{mg} / 100 \mathrm{~g})$ and guanosine $(3.45 \mathrm{mg} / 100 \mathrm{~g})$ and 5'GMP (3.57 mg/100g).
\end{abstract}




\section{Citation}

Material from this thesis was accepted for publication in International Dairy Journal on December 3, 2009 in the following form:

Christiansen, S., et al., Chemical composition and nutrient profile of low molecular weight fraction of bovine colostrum, International Dairy Journal (2010),

doi:10.1016/j.idairyj.2009.12.005 


\section{Table of Contents}

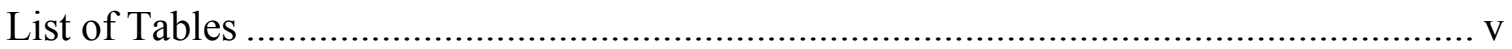

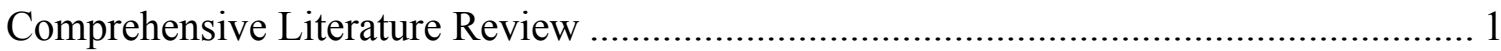

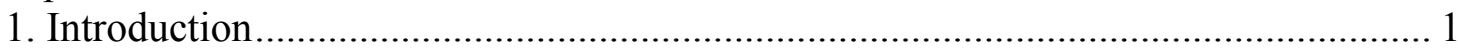

2. Colostrum and Mature Milk................................................................................. 1

3. Gross Composition of Bovine Colostrum and Mature Milk.................................... 2

4. Mineral Content of Bovine Colostrum and Mature Milk .......................................... 3

5. Fatty Acid Profile of Bovine Colostrum and Mature Milk...................................... 4

6. Proteins in Bovine Colostrum and Milk ................................................................. 6

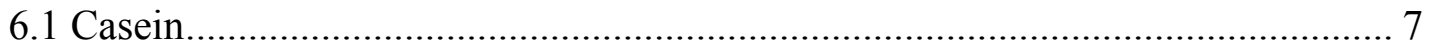

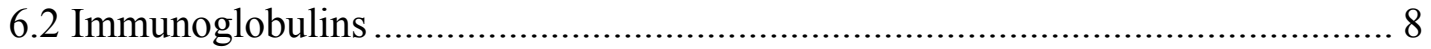

6.3 Transfer of Passive Immunity in Ungulates...................................................... 9

6.4 Transfer of Passive Immunity in Humans ....................................................... 11

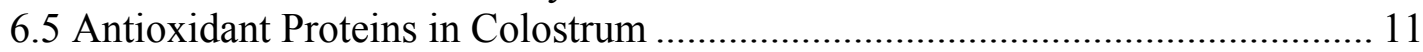

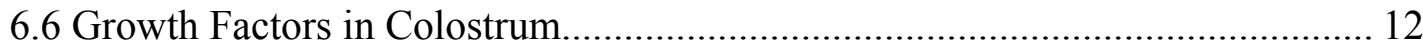

7. Oligosaccharides in Bovine Colostrum and Mature Milk ...................................... 14

7.1 Classes of Milk Oligosaccharides ................................................................... 14

7.2 Oligosaccharides in Human Colostrum and Milk.............................................. 16

7.3 Acidic Oligosaccharides in Bovine Colostrum and Mature Milk ...................... 16

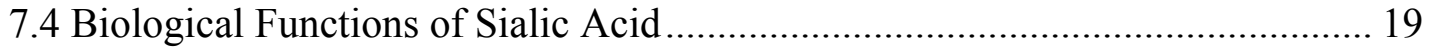

8. Colostrum Fractions as a Functional Food Ingredients ........................................ 20

8.1 Ultrafiltration in Cheesemaking and Whey Processing ................................... 21

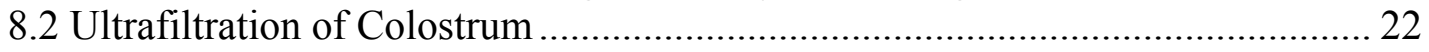

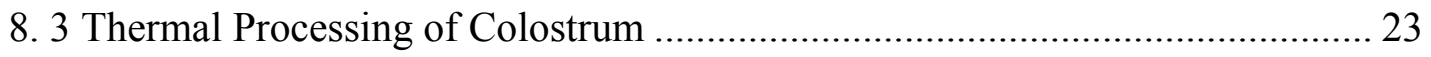

8.4 Colostrum Ultrafiltration Permeate............................................................... 24

8.5 Composition of powdered colostrum low molecular weight fraction ................ 25

Chemical composition and nutrient profile of low molecular weight fraction of bovine

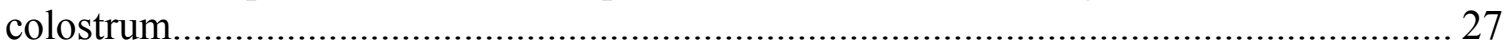

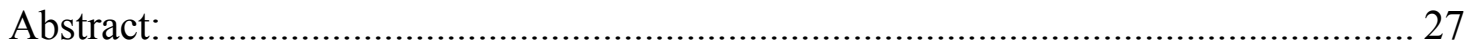

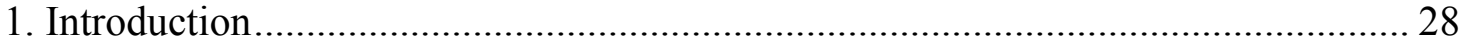

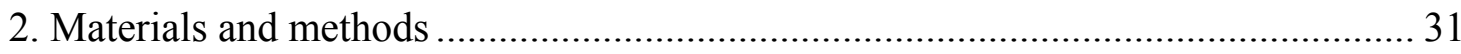

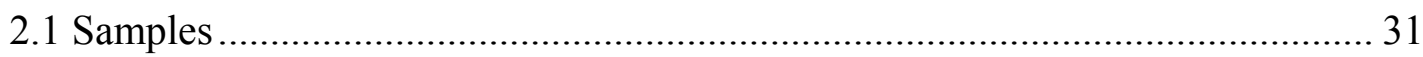

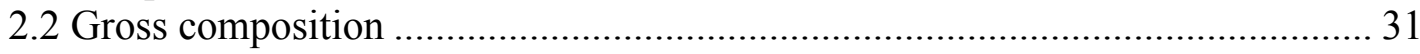

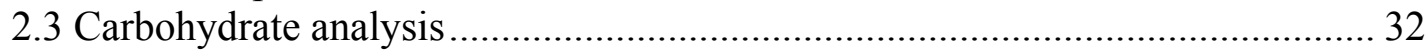

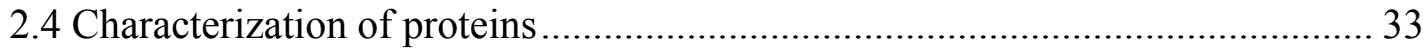

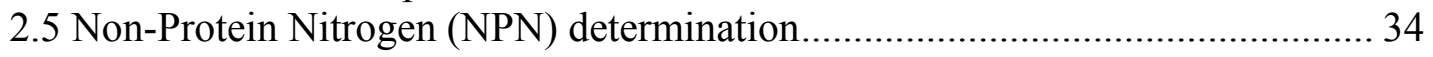

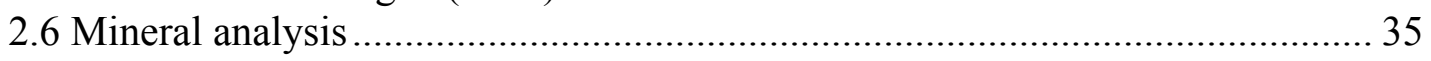

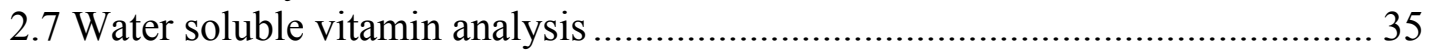

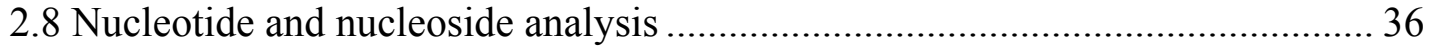

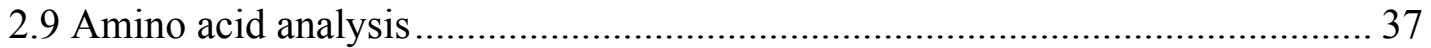

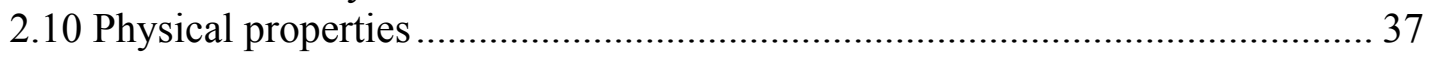

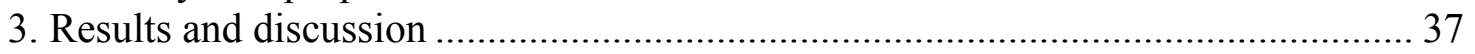




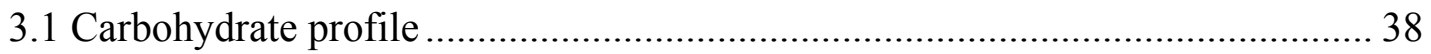

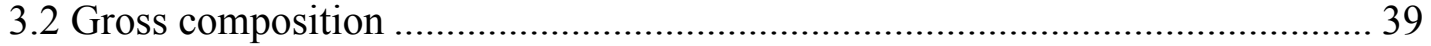

3.3 Comparison of CLMWF gross composition to milk, colostrum, and whey

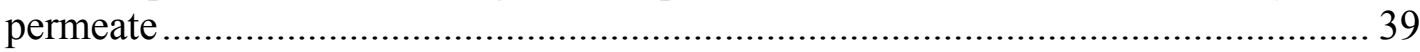

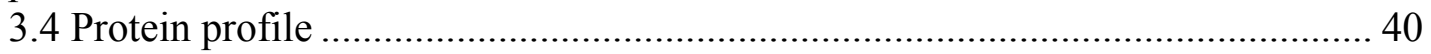

3.5 Non-Protein Nitrogen (NPN) and amino acids ……….................................... 41

3.6 Minerals and water soluble vitamins .......................................................... 42

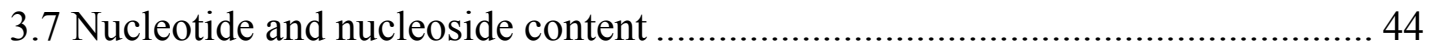

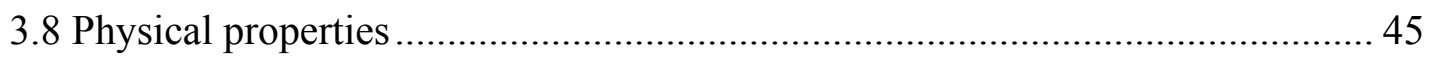

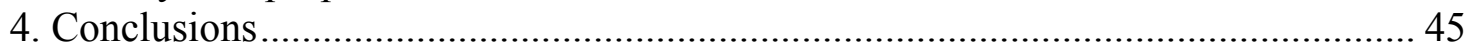

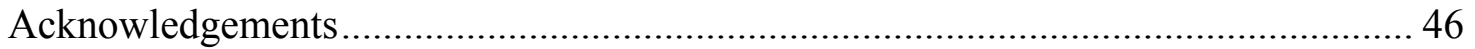

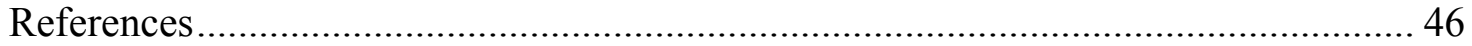

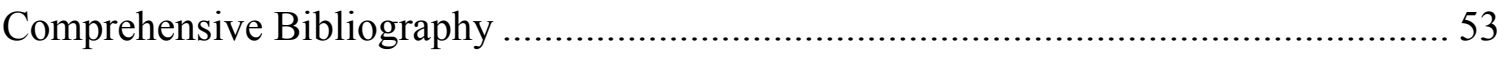




\section{List of Tables}

Table 1. Gross composition of bovine colostrum and mature milk ................................ 2

Table 2. Major mineral content of bovine colostrum and mature milk ............................ 4

Table 3. Trace mineral content of bovine colostrum and mature milk ............................. 4

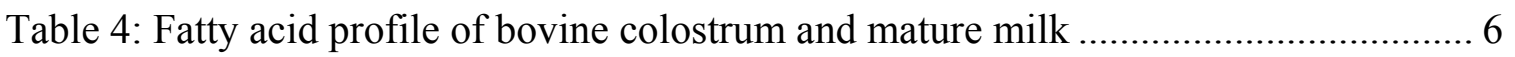

Table 5. Nitrogen distribution in bovine colostrum and mature milk.............................. 7

Table 6. Published values for total sialic acid (SA) in bovine colostrum and milk......... 17

Table 7. Published values for total oligosaccharide bound sialic acid (OBSA) in bovine

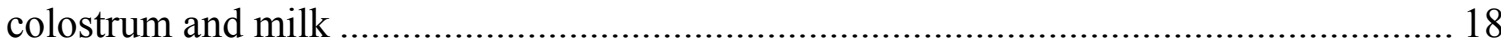

Table 8. Published values for acidic oligosaccharides in caprine milk and bovine

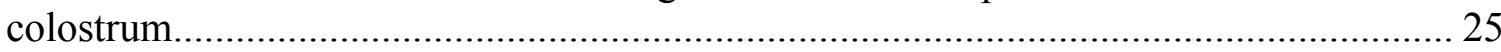

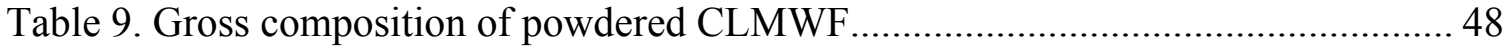

Table 10. Comparison of gross fractions of powdered CLMWF, bovine milk, bovine

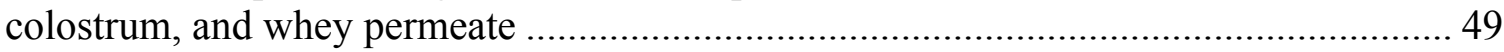

Table 11. Amino acid composition of powdered CLMWF ........................................... 50

Table 12. Nutrient content of powdered CLMWF, and comparison to published values for

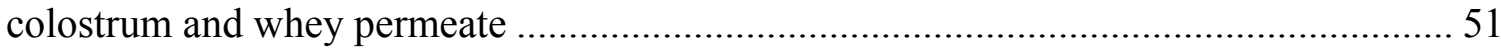

Table 13. Nucleosides and nucleotides in powdered CLMWF; comparison to published

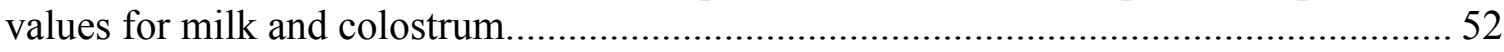




\section{Comprehensive Literature Review}

\section{Introduction}

Generically defined, milk is the fluid secretion of the mammary gland; through species-specific adaptations it largely meets the unique nutritional requirements of the neonate of the species. These requirements may be classified as needs for water, energy (provided by lactose, lipids, and excess proteins in milk), compounds required for the accretion of body mass (proteins, essential fatty acids, minerals), protective factors (immunoglobulins, lactoferrin, lactoperoxidase), and substances required for general metabolic functions (vitamins, trace minerals). The composition of the mammary glad secretion is quite dynamic over the period of lactation, reflecting the changing metabolic needs of the offspring from birth through to weaning.

\section{Colostrum and Mature Milk}

Colostrum is somewhat variously defined, as the secretion of the mammary gland produced immediately after parturition (Levieux and Ollier 1999; Nakamura, Kawase et al. 2003; Kehoe, Heinrichs et al. 2007), through two days post parturition (Martin, Martin-Sosa et al. 2001; Martin, Martin-Sosa et al. 2001; Martin-Sosa, Martin et al. 2003), through four days post parturition (Gopal and Gill 2000) or somewhat generally through the first several days after birth (Kelly 2003; Tsioulpas, Grandison et al. 2007). Within each species, the nutritional and physiological needs of the neonate during this period of very early life are typically quite specialized, and correspondingly, the 
composition of the maternal colostrum is tailored to meet these unique requirements.

There is generally considered to be a relatively quick transition in the mammary gland from the production of "true" colostrum immediately after birth to "mature milk" within several days after birth, and as shown below the chemical and nutrient composition of colostrum is substantially different from mature milk.

\section{Gross Composition of Bovine Colostrum and Mature Milk}

The table below compares the gross composition of bovine colostrum with mature bovine milk (Webb, Johnson et al. 1974; Wong 1988; Jensen 1995; Fox and McSweeney 2003; Walstra, Wouters et al. 2006; Kehoe, Heinrichs et al. 2007; Tsioulpas, Grandison et al. 2007).

Table 1. Gross composition of bovine colostrum and mature milk

\begin{tabular}{|c|c|c|c|c|c|c|c|}
\hline Reference & Time $^{\mathrm{a}}$ & Units $^{\mathrm{d}}$ & T.S. $^{\mathrm{e}}$ & Protein & Fat & Lactose & Ash \\
\hline \multicolumn{8}{|c|}{ Bovine Colostrum: } \\
\hline Kehoe, 2007 & $4 \mathrm{~h}$ & $\% \mathrm{w} / \mathrm{W}$ & $27.6 \%$ & $14.9 \%$ & $6.7 \%$ & $2.5 \%$ & $0.05 \%$ \\
\hline Tsioulpas, 2007 & $1 \mathrm{~d}$ & $\%$ & - & $16.2 \%$ & $3.6 \%$ & $2.7 \%$ & $1.2 \%$ \\
\hline \multicolumn{8}{|c|}{ Mature Bovine Milk: } \\
\hline \multirow{2}{*}{ Webb, $1974^{\mathrm{b}}$} & \multirow{6}{*}{$\begin{array}{l}\text { Mature } \\
\text { Milk }\end{array}$} & $\%$ & $12.8 \%$ & $3.5 \%$ & $3.7 \%$ & $4.9 \%$ & $0.7 \%$ \\
\hline & & $\%$ & $13.4 \%$ & $3.6 \%$ & $4.1 \%$ & $5.0 \%$ & $0.7 \%$ \\
\hline Wong, 1988 & & $\% \mathrm{~W} / \mathrm{W}$ & $12.7 \%$ & $3.2 \%$ & $3.9 \%$ & $4.6 \%$ & $0.7 \%$ \\
\hline Jensen, 1995 & & $\% \mathrm{~W} / \mathrm{W}$ & - & $3.4 \%$ & $3.7 \%$ & $4.6 \%$ & $0.7 \%$ \\
\hline Fox, 2003 & & $\%$ & $12.7 \%$ & $2.9 \%$ & $4.5 \%$ & $4.1 \%$ & $0.8 \%$ \\
\hline Walstra, $2006^{\mathrm{c}}$ & & $\% \mathrm{w} / \mathrm{W}$ & $12.9 \%$ & $3.3 \%$ & $4.0 \%$ & $4.6 \%$ & $\mathrm{f}$ \\
\hline
\end{tabular}

a. Post parturition

b. Webb cites two different sets of data: the first line is "the average composition of milk produced in the United States over the period of a year", the second line are the means of a more varied data set which includes less common breeds.

c. "Typical for milks of lowland breeds".

d. In some works, the author(s) specified "\% w/w" (g/100g), in other cases, only "\%" was noted, leaving open the question of "w/w" or "w/v" $(\mathrm{g} / 100 \mathrm{ml})$

e. Total Solids 
f. Here and throughout, “““ indicates no value was given in the reference.

The differences in the gross composition of bovine colostrum and mature milk begin to allow insight into the differences in the biological functions of the two materials. The values in Table 1 show that bovine colostrum is not only much more calorically dense than mature bovine milk ( $130 \mathrm{kCal} / 100 \mathrm{~g}$ vs $\sim 68 \mathrm{kCal} / 100 \mathrm{~g}$; Kehoe vs Walstra, e.g., here and below), but that the energy distribution is significantly different across these gross components: the energy in colostrum derived from protein is much higher than mature milk ( $\sim 46 \%$ of calories vs $\sim 19 \%$ of calories), that from fat is slightly lower ( $\sim 7 \%$ vs $\sim 53 \%$ ) and that from lactose is significantly lower ( $\sim 8 \%$ vs $\sim 27 \%)$. These variations suggest that bovine colostrum has a much different biological role than simply providing energy and nutrients to the neonate, and the composition of each of the gross fractions is examined in more detail in the paragraphs below.

\section{Mineral Content of Bovine Colostrum and Mature Milk}

The tables below outline the "major" $(\mathrm{mg} / \mathrm{L})$ and "trace" $(\mathrm{mcg} / \mathrm{L})$ mineral contents of bovine colostrum and mature bovine milk (Webb, Johnson et al. 1974; Wong 1988; Jensen 1995; Mahan and Escott-Stump 2004; Kehoe, Heinrichs et al. 2007). The value for ash in colostrum stated by Kehoe is significantly lower than those typically cited for mature bovine milk (Table 1), however, this value notwithstanding, the individual mineral results in this reference are consistently higher than the typical values cited for mature bovine milk. As shown in Tables 2 and 3, when expressed on a common basis, bovine colostrum is more rich in minerals than mature bovine milk. 
Table 2. Major mineral content of bovine colostrum and mature milk

\begin{tabular}{|c|c|c|c|c|c|c|c|c|}
\hline Mineral & Ca & P & Na & K & Fe & Mg & Zn & Cl \\
\hline Bovine Colostrum: ${ }^{\text {a }}$ \\
\hline Kehoe, 2007 & 4999 & 4719 & 1122 & 3017 & 5.33 & 777 & 40.3 & - \\
\hline
\end{tabular}

a. All values in $\mathrm{mg} / \mathrm{L}$

b. $\mathrm{mg} / \mathrm{kg}$ values converted to $\mathrm{mg} / \mathrm{L}$ assuming $1.06 \mathrm{~kg} / \mathrm{L}$ for $27.6 \% \mathrm{~T}$.S.

c. "Whole milk" values given in $\mathrm{mg} / 100 \mathrm{~g}$ converted to $\mathrm{mg} / \mathrm{L}$ assuming $1.03 \mathrm{~g} / \mathrm{mL}$ for $12.7 \%$ T.S.

Table 3. Trace mineral content of bovine colostrum and mature milk

\begin{tabular}{|c|c|c|c|c|}
\hline Mineral & Cu & I & Mn & Se \\
\hline \multicolumn{5}{|c|}{ Bovine Colostrum: ${ }^{\mathrm{a}}$} \\
\hline Kehoe, 2007 & 360 & - & 106 & - \\
\hline \multicolumn{5}{|c|}{ Mature Bovine Milk: ${ }^{\mathrm{a}}$} \\
\hline Webb, 1974 & 130 & 43 & 22 & $40-1270$ \\
\hline Jensen, 1995 & $50-200$ & $70-219$ & 21 & $10-1270^{\text {c }}$ \\
\hline
\end{tabular}

a. All values in $\mathrm{mcg} / \mathrm{L}$

b. $\mathrm{mg} / \mathrm{kg}$ values converted to $\mathrm{mg} / \mathrm{L}$ assuming $1.06 \mathrm{~g} / \mathrm{ml}$ for $27.6 \% \mathrm{~T} . \mathrm{S}$

c. Range of three studies cited for U.S.

\section{Fatty Acid Profile of Bovine Colostrum and Mature Milk}

While animal fats also contain small amounts of phospholipids, free fatty acids, and mono- and diglycerides, it is believed $>98 \%$ of animal fat is comprised of acyl triglycerides (Fomon 1993), wherein three fatty acids (acyl carboxylic acids) are esterified to a glycerol (1,2,3 propane triol) backbone. It is generally recognized that in 
plants and most animals, the individual fatty acids are synthesized de novo from 2-carbon acetyl units, and thus generally contain an even number of carbon atoms (ISEO 2006).

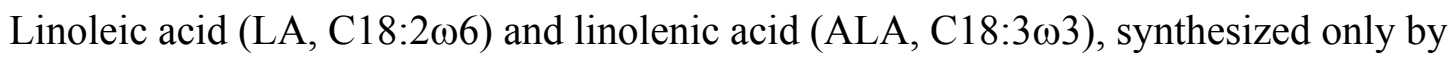
plants and considered essential in mammals, form the starting point for the synthesis of long chain polyunsaturated fatty acids (LCPUFA) through a series of chain elongation and desaturation reactions.

It is generally believed that in animals, saturated and polyunsaturated fatty acids have different metabolic fates. While saturated fatty acids are predominantly metabolized by $\beta$-oxidation for their energy content, polyunsaturated fatty acids are essential components of cell membranes, are precursors in the synthesis of prostaglandins, thromboxanes, and leukotrienes ( $\omega 6$ family), and contribute to normal visual and neurological development ( $\omega 3$ family) (Fomon 1993).

Thus, beyond its simple overall abundance in colostrum and milk (shown in Table 1), fat may be further characterized by its fatty acid profile, or an elucidation of the relative abundance of the individual fatty acids comprising the acyl triglycerides. The table below shows the fatty acid profiles of bovine colostrum and mature milk (Jensen 1995; Santschi, Witschi et al. 2009). Interestingly, aside from the difference in the overall abundance of fat in bovine colostrum and mature milk, there is little difference in the composition of the fat (fatty acid profile), as documented in these two references separated in the literature by $\sim 25$ years. 
Table 4: Fatty acid profile of bovine colostrum and mature milk

\begin{tabular}{|r|c|c|}
\hline Reference: & Santschi, 2009 $^{\mathrm{a}}$ & Jensen, 1995 \\
\hline Sample: & Colostrum & Mature Milk \\
\hline Period: & $2 \mathrm{~d}$ & $\mathrm{NS}$ \\
\hline Configuration & \multicolumn{2}{|c|}{ Percent of Fat } \\
\hline C4:0 & $3.9 \%$ & $4.5 \%$ \\
\hline C6:0 & $1.6 \%$ & $2.3 \%$ \\
\hline C8:0 & $0.8 \%$ & $1.3 \%$ \\
\hline C10:0 & $1.6 \%$ & $2.7 \%$ \\
\hline C12:0 $14: 0$ & $2.1 \%$ & $3.0 \%$ \\
\hline C16:0 & $9.2 \%$ & $10.7 \%$ \\
\hline C16:1 & $38.4 \%$ & $28.2 \%$ \\
\hline C18:0 & $2.4 \%$ & $1.8 \%$ \\
\hline C18:1 & $7.9 \%$ & $12.6 \%$ \\
\hline C18:2 & $23.0 \%$ & $21.4 \%$ \\
\hline C18:3 & $2.8 \%$ & $2.9 \%$ \\
\hline Saturated & $\mathbf{6 5 . 5 \%} \%$ & $3.2 \%$ \\
\hline Monounsaturated & $\mathbf{2 5 . 4 \%}$ & $\mathbf{6 5 . 3 \%}$ \\
\hline Polyunsaturated & $\mathbf{3 . 6 \%}$ & $\mathbf{6 . 1 \%} \%$ \\
\hline
\end{tabular}

a. Data from Table 3, column "CC", first four milkings post parturition.

\section{Proteins in Bovine Colostrum and Milk}

As shown in Table 1, the protein content of bovine colostrum is substantially higher than in the mature milk produced later, and characterization of this colostrum protein has been the historical focus of significant research, with potential applications in animal husbandry, nutritional, and economic areas. As shown in the table below, the nitrogen distribution in mature bovine milk is substantially different than in bovine colostrum. In mature milk, casein is by far the predominant protein, with the whey proteins present in 
far lesser quantities (Fox and McSweeney 2003). In contrast, the literature does not reveal that colostrum is a significant source of casein at all, rather, in the first milking post-parturition, virtually all of the protein is found in the whey fraction, primarily as Immunoglogulin G (Levieux and Ollier 1999).

Table 5. Nitrogen distribution in bovine colostrum and mature milk

\begin{tabular}{|r|c|c|c|c|c|c|}
\hline Protein & Casein & $\boldsymbol{\alpha}-\mathbf{L a}^{\mathrm{a}}$ & $\boldsymbol{\beta}-\mathbf{L g}^{\mathrm{b}}$ & $\mathbf{I g G}^{\mathrm{IgG}}$ & $\mathbf{P P}^{\mathrm{c}}$ & $\mathbf{N P N}^{\mathrm{d}}$ \\
\hline Mature milk & $78 \%$ & $3.5 \%$ & $12 \%$ & $3 \%$ & $2 \%$ & $3 \%$ \\
\hline & & & & & & \\
\hline Protein $^{\mathrm{f}}$ & Casein & $\boldsymbol{\alpha}-\mathbf{L a}^{\mathrm{a}}$ & $\boldsymbol{\beta}-\mathbf{L g}^{\mathrm{b}}$ & $\mathbf{I g G}$ & $\mathbf{B S A}^{\mathrm{e}}$ & \\
\hline Colostrum $^{\mathrm{f}}$ & - & $3 \%$ & $18 \%$ & $78 \%$ & $2 \%$ & \\
\hline
\end{tabular}

a. $\alpha$-lactalbumin

b. $\beta$-lactoglobulin

c. Proteose peptone

d. Non-protein nitrogen

e. Blood serum albumin

f. For colostrum, the values represent the distribution of $\mathrm{N}$ in protein

\subsection{Casein}

Casein is thus the predominant protein of mature bovine milk. In the classical Kjeldahl fractionation of milk proteins, caseins are, by definition, precipitated upon acidification of milk to $\mathrm{pH} 4.6$, while whey proteins remain soluble (Fox and McSweeney 2003). Casein is synthesized in the mammary gland, and serves as the main vehicle in milk for the transport of amino acids from mother to offspring. Casein is a milk-specific protein which is not present in the bloodstream; it is readily precipitated in the acid environment of the stomach, then released slowly to the intestine, where it is entirely broken down. Based on the nutritional needs of the offspring, the component amino acids of casein may be accreted into new proteins, or oxidized for their inherent energy. Casein lacks the typical secondary and tertiary structures associated with functional proteins, and 
thus, relative to whey proteins, it is more susceptible to precipitation by acid but much is more resistant to heat denaturization (Fox and McSweeney 2003). Casein is not found in any abundance in bovine colostrum, hinting that the biological function of this early post parturition secretion of the mammary gland is not simply to provide amino acids and energy to the neonate in the form of a non-functional protein structure.

\subsection{Immunoglobulins}

The mammalian immune system is composed of humoral and cellular systems which function together to provide the individual with systemic protection against infection by microorganisms. The humoral component of immunity may be generally defined as soluble biomolecules produced in response to an infectious challenge when certain leukocytes (lymphocytes) are stimulated to differentiate into plasma cells, which produce immunoglobulin proteins (or antibodies) directed against specific surface antigens of the invading organism. The cellular component of the immune system is comprised of other classes of leukocytes (neutrophils, macrophages), which protect the host organism by producing chemotoxins and by direct phagocytosis of invading microorganisms. The humoral and cellular systems function synergistically in that the attachment of immunoglobulins to an invading microorganism enhances phagocytosis (Fox and McSweeney 2003).

Mammalian immunoglobulins (Ig) may be divided into five classes, termed IgM, IgA, IgD, IgG, and IgE. Immunoglogulin $\mathrm{G}(\mathrm{IgG})$ is a monomeric glycoprotein having a molecular weight of $\sim 160 \mathrm{kDa}$ consisting of four sub-unit polypeptides composed of two 
identical heavy chains and two identical light chains. $\operatorname{IgG}$ is the predominant immunoglobulin, and the most abundant protein in bovine colostrum, where it is found predominantly in the $\operatorname{IgG}_{1}$ subclass (Gapper, Copestake et al. 2007).

\subsection{Transfer of Passive Immunity in Ungulates}

Ungulate neonates are born essentially agammaglobulinemic (Fox and McSweeney 2003), and at the time of parturition, maternal $\operatorname{IgG}_{1}$ from the circulating pool in the blood is actively concentrated in the secretion of the mammary gland (Levieux and Ollier 1999). IgA, a dimer, and IgM, a pentamer, are also actively transported into the mammary gland by an epithelial cell surface receptor, although these immunoglobulins represent only a small portion of the total immunoglobulin in bovine colostrum ( $\sim 2 \%$ and $\sim 9 \%$, respectively) (Fox and McSweeney 2003). Immunoglobulins are transferred to the neonate via the colostrum, and substantial amounts of IgG are absorbed intact by enterocytes of the jejunum via a non-selective macromolecular transport system. The absorbed IgG is passed directly into the portal or lymphatic circulation and ultimately confers passive systemic humoral immunity to the neonate, primarily protecting the gut mucosa from pathogenic organisms (Gapper, Copestake et al. 2007).

The neonate's ability to absorb intact macromolecules (including $\operatorname{IgG}$ ) is short lived, with closure of the bovine enterocyte occurring within 24 hours after birth (Fox and McSweeney 2003). The mother can secrete as much as $550 \mathrm{~g}$ of $\mathrm{IgG}$ in the week periparturition (Brandon, Watson et al. 1971) to a total of $2 \mathrm{~kg}$, the majority immediately after birth and largely coinciding with this period of nonselective macromolecular 
absorption by the neonate. It is widely recommended that the bovine neonate consume at least $100 \mathrm{~g} \operatorname{IgG}$ in the first 24 hours of life (Quigley, Strohbehn et al. 2001); delay in consumption (or feeding) of colostrum significantly increases the animal's risk of disease and mortality.

The concentration of $\operatorname{IgG}_{1}$ in bovine colostrum varies widely, based on the mother's number of previous pregnancies, the rate of transfer of the compound to the colostrum by the mammary gland, and the actual volume of colostrum produced. Typical concentrations of $40-90 \mathrm{mg} / \mathrm{ml}$ are reported (Quigley, Strohbehn et al. 2001; Mehra, Marnila et al. 2006; Kehoe, Heinrichs et al. 2007) $(15-33 \%$ w/w of colostrum on a solids basis) but values of $180-200 \mathrm{mg} / \mathrm{ml}$ have also been recorded (Fox and McSweeney 2003; Mehra, Marnila et al. 2006). In contrast, in mature bovine milk, the IgG concentration falls to $<1 \mathrm{mg} / \mathrm{ml}$ (Kummer, Kitts et al. 1992; Conessa, Lavilla et al. 2005; Mehra, Marnila et al. 2006).

It is believed that the circulating maternal immunoglobulin pool reflects specific infectious challenges to which the individual's humoral immune system has previously responded. This has prompted the creation of hyperimmune bovine colostrum (HBC), where, pre-parturition, the mother is inoculated with killed bacteria of a specific strain in order to create an immune response to that organism. The colostrum of an animal thus treated has a high titer of antibody directed against the specific pathogen; antibodies to numerous organisms have been produced and collected, including Vibrio cholera, Helicobacter pylori, Shigella, Cryptosporidium, and rotavirus (Kelly 2003). 


\subsection{Transfer of Passive Immunity in Humans}

The transfer of passive immunity in humans follows a much different route than the bovine model described above, with immunoglobulin transport occurring in utero during the third trimester of pregnancy. As a result, immunoglobulins are found at much lower concentrations in human colostrum: IgA (the predominant form) at $<20 \mathrm{mg} / \mathrm{ml}$, and $\operatorname{IgG}$ at $<1 \mathrm{mg} / \mathrm{ml}$ (Fox and McSweeney 2003). In the human neonate, there is no macromolecular transport by the enterocyte to the portal blood stream, and intestinal proteases (pepsin, trypsin, chymotrypsin, carboxypeptidase, elastase) cleave milk Igs into their component light- and heavy peptide chains, although the $\sim 75 \mathrm{kDa}$ secretory component (SC) is believed to confer some protection to secretory IgA (Mehra, Marnila et al. 2006). In the human infant, the biological fate of ingested immunoglobulin proteins is to remain in the lumen of the intestine where they confer some measure of protection against enteric pathogens (Fox and McSweeney 2003), and indeed, in specific human clinical trials the immunoglobulins in bovine milk have been shown to be effective against enteropathic and enterotoxigenic E. coli, rotavirus, and Shigella flexnrei (LiChan, Kummer et al. 1995).

\subsection{Antioxidant Proteins in Colostrum}

The protein fraction of bovine colostrum also contains antioxidant enzymes which reduce the reactive oxygen species (ROS) and strong oxidizers typically present in colostrum as a result of normal biological processes. Certain leukocytes in colostrum (polymorphonuclear neutrophils, phagocytic monocytes) generate bacteriocidal ROS 
(superoxide) and strong oxidizers (hydrogen peroxide) as a part of normal cellular mediated immunity. Bovine colostrum contains the enzymes superoxide dismutase (SOD), catalase (CAT), and glutathione peroxidase (GSH-Px) (Przybylska, Albera et al. 2007). SOD (MW $31-33 \mathrm{kDa}$ ) catalyzes the conversion of superoxide anion $\left(\mathrm{O}_{2}{ }^{-}\right)$to hydrogen peroxide $\left(\mathrm{H}_{2} \mathrm{O}_{2}\right)$ and is found in the aqueous phase of milk or colostrum. Both CAT (MW $\sim 240 \mathrm{kDa}$ ), largely bound to the membranes of fat globules, and GSH-Px (MW $\sim 25 \mathrm{kDa}$ ), a selenium containing enzyme, catalyze the conversion of hydrogen peroxide to oxygen and water.

Bovine colostrum also contains two proteins which have bacteriostatic or bacteriocidal properties. Lactoferrin (LF, MW $76-80 \mathrm{kDa}$ ) is believed to bind excess iron found in the gut, required by pathogenic bacteria for proliferation. By binding reactive ferric iron, $L F$ is also believed to protect lipids from iron induced peroxidation (Przybylska, Albera et al. 2007). Relative to other species, the LF content of bovine colostrum is low (Kehoe, Heinrichs et al. 2007). Lactoperoxidase (LP, MW 78 kDa), which is found at very low levels in human milk and colostrum, creates ROS at the expense of hydrogen peroxide as part of the natural host defense system against microorganisms (Przybylska, Albera et al. 2007).

\subsection{Growth Factors in Colostrum}

Bovine colostrum also contains the peptide / growth factors insulin-like growth factor-1 (IGF-1) and -2 (IGF-2), transforming growth factor $\beta$-2 (TGF- $\beta 2$ ), growth hormone (GH), epidermal growth factor (EGF), and the cytokines interleukin 1- $\beta$ (IL- 
$1 \beta)$, interleukin 6 (IL-6), tumor necrosis factor alpha (TNF- $\alpha$ ), and interferon-gamma (IL- $\gamma)$ (Elfstrand, Lindmark-Mansson et al. 2002; Kelly 2003).

Clinical trials evaluating the effects of these factors through supplementation of the diet with bovine colostrum have had mixed results (Kelly 2003). In athletes, supplementation with bovine colostrum was hoped to increase the level of IGF-1 in serum: bovine colostrum IGF-1 is identical to human IGF-1, and is believed to have an anabolic effect. Unfortunately, active intervention using dietary supplementation with colostrum did not increase the levels of serum IGF-1 above normal day to day variability, and there were no significant increases in serum insulin, testosterone, or growth hormone, or any improvement in physical performance. The susceptibility of IGF-1 to digestive enzymes and a mechanism whereby the compound could be absorbed intact into the bloodstream require further elucidation. Other studies were performed to determine the effect of supplementation of the diet with colostrum on gastrointestinal (GI) inflammation caused by the use of non-steroidal anti-inflammatory drugs (NSAIDS). In one study, supplementation with bovine colostrum prior to NSAID administration resulted in decreased intestinal permeability, indicating a lessening of inflammation and tissue damage. A second study supplemented the diet of individuals on NSAID therapy for at least a year with bovine colostrum; in this case, no significant anti-inflammatory or ameliorative effect was observed.

To date, supplementation with these growth factors has been studied using whole colostrum, rather than a colostrum fraction enriched in these compounds. The isolation of 
growth factors from bovine colostrum has not been achieved, and may prove difficult, with the compounds present in colostrum only at low concentrations: IGF-1 (MW 7649 Da) $\sim 3.0 \mathrm{mg} / \mathrm{g}$ in bovine colostrum on a solids basis, TGF- $\beta 2$ (MW of bioactive dimer 25 $\mathrm{kDa}$ ), $\sim 1 \mathrm{mg} / \mathrm{g}$ on a solids basis, and GH (MW $22 \mathrm{kDa}$ ), $\sim 0.6 \mathrm{ng} / \mathrm{g}$ on a solids basis. Unfortunately, the compounds also appear to be susceptible to thermal processing: treatment of whole colostrum at $60^{\circ} \mathrm{C} / 30 \mathrm{~min}$ destroyed $\mathrm{GH}$, and reduced the concentration of IGF-1 by $33 \%$, although TGF- $\beta 2$ was not effected. Substantial losses of GH and IGF-1 were also noted after storage of whole colostrum at $-20^{\circ} \mathrm{C}$ for two months (Elfstrand, Lindmark-Mansson et al. 2002), indicating that creating of a functional food ingredient or dietary supplement enriched in these compounds will not be without challenge. Significant further study is required to determine the levels of dietary supplementation required to obtain a specific beneficial health effect, and technological challenges must be resolved to concentrate these compounds in a purified form.

\section{Oligosaccharides in Bovine Colostrum and Mature Milk}

\subsection{Classes of Milk Oligosaccharides}

Oligosaccharides, strictly defined as carbohydrates having between 3 and 10 monosaccharide units covalently linked through glycosidic bonds (Mehra and Kelly 2006), represent a major class of specialized bioactive compounds found in colostrum. The oligosaccharides found in mammary gland secretions are typically lactose-based, and 
are thus much different than those found in plant derived food ingredients. Mammalian oligosaccharides can be divided into two general classes:

- Neutral oligosaccharides, or galacto-oligosaccharides (GOS), in which additional galactose monomers are attached to the galactose molecule of lactose;

- Acidic oligosaccharides, or those that contain one or more residues of the class of compounds collectively known as sialic acid, which are $\mathrm{N}$ - and O- substituted derivatives of the nine carbon monosaccharide $\mathrm{N}$-acetyl neuraminic acid (NANA).

The GOS content of bovine colostrum and mature milk requires further clarification, but in general, neutral oligosaccharides are believed to have a prebiotic effect, stimulating the growth of Bifidobacteria and Lactobacilli (Martinez-Ferez, Rudloff et al. 2006). In contrast, sialic acid containing oligosaccharides are believed to have more complicated and diverse biological roles in the neonate, as described below.

Sialic acid containing oligosaccharides are widely distributed in animals and are common components of the mucoproteins, mucopolysaccharides, and mucolipids (Stecher 2001) found in cell membranes throughout the body. The distribution and function of sialic acid containing compounds in colostrum and milk have not been completely elucidated, however sialic acid is found in the free form, as well as bound to glycoproteins, caseins, oligosaccharides (Martin, Martin-Sosa et al. 2001) and in lipid bound forms (Martin, Martin-Sosa et al. 2001). Within each species, the abundance of sialic acid varies by stage of lactation, and the forms (free and bound) in which it is 
found. In general, colostrum contains higher levels of total oligosaccharides and sialic acid containing compounds than does the mature milk produced later. Significant differences in sialic acid content in mammary gland secretions are also noted between species, making the overall distribution of sialic acid in colostrum and milk quite complicated.

\subsection{Oligosaccharides in Human Colostrum and Milk}

Human colostrum is reported to have a total oligosaccharide (neutral + acidic) content of $24 \mathrm{mg} / \mathrm{ml}$, dropping to $13 \mathrm{mg} / \mathrm{ml}$ in mature milk; oligosaccharides are thus the third most abundant component of human milk (at $1.3 \% \mathrm{w} / \mathrm{v})$ behind lactose $(6.8 \%)$ and fat (3.9\%), and are found in larger quantities than protein (1.0\%) (Gopal and Gill 2000). The total sialic acid content (free + bound forms) of human colostrum is reported as 1.55 $\mathrm{mg} / \mathrm{ml}$, dropping to $0.32 \mathrm{mg} / \mathrm{ml}$ after 3 months of lactation (Wang, Brand-Miller et al. 2001). The oligosaccharide-bound sialic acid (OBSA) content of human colostrum is reported as $0.960 \pm 0.216 \mathrm{mg} / \mathrm{ml}$, dropping to $0.354 \pm 0.129 \mathrm{mg} / \mathrm{ml}$ after one month of lactation (Martin-Sosa, Martin et al. 2003).

\subsection{Acidic Oligosaccharides in Bovine Colostrum and Mature Milk}

As shown in the table below, the reported values for total sialic acid (free + bound forms) in bovine colostrum and mature milk (Martin, Martin-Sosa et al. 2001; Nakamura, Kawase et al. 2003; McJarrow and van Amelsfort-Schoonbeek 2004) are somewhat variable, likely influenced by the period of collection and breed of animal studied. 
Nonetheless, the total sialic acid content of colostrum obtained from the first milking post parturition rivals that of human colostrum.

Table 6. Published values for total sialic acid (SA) in bovine colostrum and milk

\begin{tabular}{|c|c|c|c|c|}
\hline & \multicolumn{2}{|c|}{ Colostrum } & \multicolumn{2}{|c|}{ Mature Milk } \\
\hline Breed & Collection & Total SA ${ }^{\mathrm{a}}$ & Collection & Total SA $^{\mathrm{a}}$ \\
\hline Spanish-Brown & $\begin{array}{l}2 \text { days post } \\
\text { parturition }\end{array}$ & $0.55 \pm 0.19$ & 3 mos. & 0.15 \\
\hline Holstein & $\begin{array}{c}\text { Immediately } \\
\text { after parturition }\end{array}$ & $1.7 \pm 0.5$ & $\begin{array}{l}7 \text { days post } \\
\text { parturition }\end{array}$ & 0.15 \\
\hline Jersey & \multirow{2}{*}{$\begin{array}{l}\text { First milking } \\
\text { post-parturition }\end{array}$} & $1.349 \pm 0.436$ & \multirow{2}{*}{ NR } & \multirow{2}{*}{ NR } \\
\hline Fresian & & $1.184 \pm 0.436$ & & \\
\hline
\end{tabular}

a. All values: $\mathrm{mg} / \mathrm{ml}$

In bovine mammary secretions, the acidic oligosaccharide fraction is comprised mainly of 3'- and 6'-sialyllactose (3'SL, 6'SL), sialyllactosamine (6'SLN), and disialyllactose (DSL); these compounds may be quantified individually or reported as a total oligosaccharide-bound sialic acid (OBSA). While the overall range of acidic oligosaccarides in bovine milk is less diverse than what is found in human milk (Martin, Martin-Sosa et al. 2001; Nakamura, Kawase et al. 2003; Martinez-Ferez, Rudloff et al. 2006), 3'SL and 6'SL are the major OBSA forms in both bovine and human mammary gland secretions (Gopal and Gill 2000).

As with total sialic acid, as shown in the table below, the reported values for OBSA in bovine colostrum and mature milk (Martin, Martin-Sosa et al. 2001; Martin-Sosa, Martin et al. 2003; Nakamura, Kawase et al. 2003; McJarrow and van Amelsfort-Schoonbeek 2004) are somewhat variable, again influenced by the period of collection and breed of 
animal studied. Again, analogous to total sialic acid content, the OBSA content of colostrum obtained from the first milking post parturition rivals that of human colostrum.

Table 7. Published values for total oligosaccharide bound sialic acid (OBSA) in bovine colostrum and milk

\begin{tabular}{|c|c|c|c|c|}
\hline & \multicolumn{2}{|c|}{ Colostrum } & \multicolumn{2}{|c|}{ Mature Milk } \\
\hline Breed & Collection & OBSA $^{\mathrm{a}}$ & Collection & OBSA $^{\mathrm{a}}$ \\
\hline $\begin{array}{l}\text { Spanish- } \\
\text { Brown }\end{array}$ & $\begin{array}{l}2 \text { days post } \\
\text { parturition }\end{array}$ & 0.217 & 3 mos. & 0.024 \\
\hline $\begin{array}{l}\text { Spanish- } \\
\text { Brown }\end{array}$ & $\begin{array}{l}2 \text { days post } \\
\text { parturition }\end{array}$ & $0.218 \pm 0.071$ & 3 mos. & $0.032 \pm 0.008$ \\
\hline Holstein & $\begin{array}{c}\text { Immediately after } \\
\text { parturition }\end{array}$ & 1.11 & $\begin{array}{l}3 \text { days post } \\
\text { parturition }\end{array}$ & 0.21 \\
\hline Jersey & \multirow{2}{*}{$\begin{array}{l}\text { First milking post- } \\
\text { parturition }\end{array}$} & $1.506 \pm 0.535$ & \multirow{2}{*}{$\begin{array}{c}\text { Seasonal } \\
\text { pool }\end{array}$} & \multirow{2}{*}{0.074} \\
\hline Fresian & & $1.364 \pm 0.593$ & & \\
\hline
\end{tabular}

a. All values: $\mathrm{mg} / \mathrm{ml}$

The reported levels of lipid-bound sialic acid (LBSA) indicate that bovine colostrum is a richer source of this material than is the mature milk produced later $(3.5 \mathrm{mg} / \mathrm{kg}$ vs 0.9 $\mathrm{mg} / \mathrm{kg}$, respectively), but that this fraction represents only a small portion of the total sialic acid; LBSA is mostly associated with lipid membranes in colostrum and milk (Martin, Martin-Sosa et al. 2001). In bovine colostrum, the content of protein-bound oligosaccharides is quite high, $(0.350 \mathrm{mg} / \mathrm{ml})$ : this fraction is known to be largely incorporated in glycoprotein immunoglobulins (Martin, Martin-Sosa et al. 2001). The content, distribution, and biological functions of protein-bound acidic oligosaccharides in milk remains to be more fully elucidated. 


\subsection{Biological Functions of Sialic Acid}

Sialic acid is believed to have two important and distinctly different roles in neonatal nutrition. In the cell membranes of neural tissues, sialic acid is accreted in large quantities in the form of gangliosides, a class of glycosphingolipids that contain sphingosine, to which is attached a fatty acid and an oligosaccharide containing one or more sialic acid residues (Boulton, Baker et al. 1988). Although sialic acid can be synthesized from simple sugar precursors, it is hypothesized to be a conditionally essential nutrient in human infants, and it is believed that exogenous sialic acid is readily incorporated into gangliosides in the cell membranes of neural tissues, increasing the rate of neural tissue accretion and improving the establishment and function of synaptic pathways (Wang, Brand-Miller et al. 2001). This implies that in the infant, sialic acid containing oligosaccharides are either absorbed intact, or that sialic acid is enzymatically cleaved from the oligosaccharide, absorbed, and incorporated in a new oligosaccharide.

Sialic-acid containing oligosaccharides (OBSA) are also believed to have two roles in promoting gut health. Similar to GOS, OBSA may promote colonization of the GI tract by beneficial bifidobacterial flora. Additionally, based on the structural similarity of OBSA to glycoproteins and glycolipids found on cell membranes, soluble acidic oligosaccharides may act as receptor analogs for gut pathogens, preventing their adhesion to the epithelial cell membrane and then initiating infection (Martin, Martin-Sosa et al. 2001). This implies that sialic acid containing oligosaccharides are not broken down by the enzymes of the small intestine. 


\section{Colostrum Fractions as a Functional Food Ingredients}

Bovine colostrum is not normally consumed as part of the human diet. Compared to the casein-dominant proteins of mature milk, the whey-dominant proteins of colostrum are more likely to be denatured at the temperatures used to process commercial fluid milk, causing frequent fouling of thermal processing equipment and the development of off flavors in dairy products. Accordingly, much of the historical analytical research on bovine colostrum centered on detecting its presence in raw milk supplies, from which it is excluded by statute in most jurisdictions (Levieux and Ollier 1999).

It is clear from the literature that there is no consensus on a precise definition of colostrum, or standardization in the collection or processing of bovine colostrum. It is also apparent that the first milking post parturition contains the highest quantities of the immunoglobulins and oligosaccharides unique to bovine colostrum, and that in subsequent milkings the mammary gland secretion quickly transitions towards mature milk, containing higher quantities of lactose and casein. As described below, common dairy processing techniques can be applied to bovine colostrum to recover its immunoprotein and oligosaccharide fractions, which have the greatest potential for use as functional food ingredients. Given the heat-sensitive nature of immunoglobulin proteins, colostrum based functional food ingredients require carefully controlled thermal processing in order to create a product which is safe for human consumption, while maintaining the functional integrity of the component proteins. Given the different biological functions of the immunoglobulin and oligosaccharide fractions, once purified, 
each could be used as an ingredient in functional foods with specific (and different) intended biological effects.

\subsection{Ultrafiltration in Cheesemaking and Whey Processing}

As described below, the processing of bovine colostrum into functional food ingredients utilizes ultrafiltration (UF), a standard dairy processing technique which originally found application in the processing of whey, a byproduct of the cheese-making process. Whey is the residual aqueous fraction, or serum, remaining after the removal of the precipitated solid curds. Cheese-making whey contains $\sim 7 \%$ total solids, of which $4.9 \%$ is lactose, $0.9 \%$ is protein, and $0.5 \%$ is ash (Gillies 1974). Historically, the disposal of whey presented a significant challenge to the cheese-making industry: due to its high content of readily oxidizable carbohydrate and protein, it places a high demand on municipal wastewater treatment plants, and without additional processing, it has limited utility as an ingredient in processed foods. Advances in material sciences and dairy processing combined in the 1970's to create the process of ultrafiltration (UF), allowing for the separation of the dissolved components of whey based on their molecular weight, using a synthetic filter media having a specific molecular weight cut-off based on pore size and structure.

In the UF of whey derived from cheese-making, a $5 \mathrm{kDa}$ cut-off filter is typically used; whey is passed across the membrane filter, which retains molecules having a molecular weight above this cut-off limit. In cheese-making whey UF, the whey proteins glycomacropeptide ( $8 \mathrm{kDa}), \alpha$-lactalbumin $(14 \mathrm{kDa})$, and $\beta$-lactoglobulin $(18 \mathrm{kDa})$ are 
thus concentrated in the "retentate" (the retained fraction), while molecules with molecular weights below the cut off limit ( primarily lactose and mineral ions) flow through the membrane creating a "permeate". The retentate derived from the UF of cheese-making whey is suitable for spray drying, producing a low moisture powder (whey protein concentrate, WPC) having a protein content as high as $80 \% \mathrm{w} / \mathrm{w}$ and finding widespread use as a food ingredient. The permeate derived from the UF of cheese-making whey is a rich source of lactose, which is easily recovered by recrystallization, and also finds use as a food ingredient.

\subsection{Ultrafiltration of Colostrum}

The application of standard dairy processing techniques to bovine colostrum results in the creation of a powdered product that contains as much as $80 \% \mathrm{w} / \mathrm{w}$ protein and $50 \%$ w/w IgG. Early bovine colostrum is first batch pasteurized, then de-fatted (skimmed), decaseinated (by $\mathrm{pH}$ adjustment, or the use of rennet), and selectively ultrafiltered to concentrate proteins. The immunoglobulins found in colostrum (primarily IgG, MW 160 $\mathrm{kDa}$ ) are easily separated from the lower molecular weight components by UF, with the UF retentate spray dried to create a stable, low moisture powder. Despite the obvious species specific differences in the transfer of immunity described previously, bovine colostrum has become a valuable raw material in its own right, with an annual market for IgG-containing protein concentrates of at least \$100M USD (Gapper, Copestake et al. 2007), with the material sold as human dietary supplement powders, sachets, capsules, tablets, liquid supplements, (Mehra, Marnila et al. 2006) or for use in infant formula. 


\section{3 Thermal Processing of Colostrum}

The manufacture of IgG concentrates from colostrum requires careful evaluation and control of thermal processes in order to maintain the biological activity of the immunoglobulin molecule. Bovine colostrum $\operatorname{IgG}_{1}$ has a highly refined tertiary structure which confers to it the ability to selectively attach to the antigenic site on the pathogen against which it is directed, and this structure must be maintained to preserve the biological activity of the molecule. Bovine $\operatorname{IgG}_{1}$ denatures or unfolds rapidly at temperatures above $75^{\circ} \mathrm{C}$ (Copestake, Indyk et al. 2006), consequently losing this bioactivity. IgG denaturization occurs at a temperature near the minimum requirements for legal pasteurization (USFDA 2007) of $72^{\circ} \mathrm{C} / 15 \mathrm{sec}$, and well below those typically used for HTST $\left(89^{\circ} \mathrm{C} / 1.0 \mathrm{sec}\right.$ to $\left.100^{\circ} \mathrm{C} / 0.01 \mathrm{sec}\right)$ or UHT processing.

Heat treatment of commercial fluid milks (containing $\mathrm{IgG}$ at $0.5 \mathrm{mg} / \mathrm{ml}$ ) by legal batch pasteurization $\left(63^{\circ} \mathrm{C} / 30 \mathrm{~min}\right)$ did not cause a loss of IgG activity, however losses of 26 41\% were observed after HTST, and no activity remained after UHT treatment (Li-Chan, Kummer et al. 1995). Other studies produced similar results, showing no loss of $\operatorname{IgG}_{1}$ in colostrum after treatment at $60^{\circ} \mathrm{C} / 45 \mathrm{~min}$ (although $\mathrm{IgG}_{2}$ and $\mathrm{IgA}$ were reduced by $\sim 30 \%$, and IgM destroyed completely) (Elfstrand, Lindmark-Mansson et al. 2002), and losses in IgG activity of $21-78 \%$ in HTST milk, and $>99 \%$ in UHT milk (Kummer, Kitts et al. 1992). 


\subsection{Colostrum Ultrafiltration Permeate}

The UF process used to concentrate IgG from colostrum (described above) necessarily has as its by product a UF permeate, a concentrate of the low molecular weight compounds of the colostrum. Among other substances, this low molecular weight fraction can reasonably be expected to contain various neutral (GOS) and acidic (sialyllactose, sialyllactosamine, and disialyllactose) oligosaccharides originally found in the colostrum. Although the technique has not been applied to bovine colostrum or it's UF permeate, published research has shown the ability of a two-step UF process (referred to as sequential ultrafiltration / diafiltration, or UF / DF) to selectively concentrate and recover these oligosaccharides from caprine milk (Martinez-Ferez, Rudloff et al. 2006).

As summarized in the table below, the concentrations of acidic oligosaccharides in mature caprine milk used as a starting material for the UF / DF process are far lower than the published values for these compounds in bovine colostrum, suggesting that the latter would be a superior raw material and provide a better yield (Martin-Sosa, Martin et al. 2003; Nakamura, Kawase et al. 2003; McJarrow and van Amelsfort-Schoonbeek 2004; Martinez-Ferez, Rudloff et al. 2006). 
Table 8. Published values for acidic oligosaccharides in caprine milk and bovine colostrum

\begin{tabular}{|c|c|c|c|c|c|}
\hline & \multicolumn{5}{|c|}{$\mathrm{mg} / \mathrm{ml}$ in... } \\
\hline & & \multicolumn{4}{|c|}{ Bovine Colostrum } \\
\hline Compound & Caprine Milk & Ref. 1 & Ref. 2 & Ref. 3 & Ref. 4 \\
\hline 3'SL & $0.03-0.05$ & 0.320 & $0.853 \pm 0.262$ & $0.867 \pm 0.344$ & $0.681 \pm 0.298$ \\
\hline 6'SL & $0.05-0.07$ & 0.118 & $0.141 \pm 0.062$ & $0.136 \pm 0.038$ & $0.243 \pm 0.091$ \\
\hline DSL & $0.001-0.005$ & 0.141 & - & $0.283 \pm 0.138$ & $0.201 \pm 0.128$ \\
\hline 6'SLN & - & 0.188 & $0.117 \pm 0.049$ & $0.220 \pm 0.064$ & $0.239 \pm 0.097$ \\
\hline
\end{tabular}

1. Spanish Brown, 2 days post parturition

2. Holstein, immediately after parturition

3. Jersey, first milking post parturition

4. Fresian, first milking post parturition

\subsection{Composition of powdered colostrum low molecular weight fraction}

Colostrum UF permeate may also be dried to create a stable, low moisture powder with potential use as a food ingredient or dietary supplement in its own right. To the author's knowledge, there is no previously published research establishing the basic chemical composition of such a powdered ultrafiltration permeate made from de-fatted de-caseinated bovine colostrum. In the following original research, the chemical and nutrient composition of this powdered "colostrum low molecular weight fraction" (CLMWF, as Sterling Technology Immunel $\left.{ }^{\circledR}\right)$ is characterized. Ash, fat, mineral content, and taurine were determined using compendial methodologies (Horwitz and G. Latimer 2006). Protein content was estimated based on total nitrogen content as determined by combustion (Simonne, Simonne et al. 1997), and determination of the proportion of nitrogen is found in the protein- and non-protein-nitrogen (NPN) fractions. Carbohydrates were individually quantified by high pressure liquid chromatography 
(Indyk, Edwards et al. 1996) with their levels confirmed by a separate gas chromatographic analysis (Mason and Slover 1971). The amino acid composition of the CLMWF was determined (Schuster 1988; Barkholt 1989; Horwitz and G. Latimer 2006), along with residual IgG content (Copestake, Indyk et al. 2006). Individual determinations were performed for water soluble vitamins (Woollard and Indyk 2002), L-carnitine (Starkey, Denison et al. 2008), and nucleos(t)ides (Olivartes and Verdys 1988).

Overall, the chemical composition of CLMWF proved to be somewhat similar to published values (Boumba, Voutsinas et al. 2001; Beucler, Drake et al. 2005) for the lactose-dominant UF permeate obtained from cheese-making whey, but also bore comparison to published values for mature bovine milk (Fox and McSweeney 2003) and colostrum (Kehoe, Heinrichs et al. 2007); its nutrient composition was compared to previously published values for taurine and L-carnitine (Woollard and Indyk 1993; Ferreira 2003), and nucleos(t)ides (Schlimme, Martin et al. 2000). 


\title{
Chemical composition and nutrient profile of low molecular weight fraction of bovine colostrum
}

\author{
Scott Christiansen ${ }^{1}$, Mingruo Guo ${ }^{1 *}$ and Derek Kjelden ${ }^{2}$ \\ ${ }^{1}$ Department of Nutrition and Food Sciences, University of Vermont, Burlington, Vermont, USA, ${ }^{2}$ Sterling \\ Technologies, Brookings, South Dakota, USA.
}

\begin{abstract}
Bovine colostrum collected within 12h of parturition was de-fatted, decaseinated, and ultrafiltered (UF) using a $5 \mathrm{kDa}$ cut-off membrane; the resulting UF permeate was freeze dried to create a powder with possible use as a functional food ingredient. Samples representative of five lots of this powdered "colostrum low molecular weight fraction" were analyzed for chemical composition and nutrient profile. The average contents of fat, moisture, and ash were $0.6 \%, 1.7 \%$, and $8.3 \%$, respectively. Carbohydrate analysis showed an average of $58.2 \%$ lactose monohydrate with no monosaccharides, other disaccharides, trioses, or tetroses detected. The total nitrogen content averaged $1.13 \%$, with $74 \%$ of this in the non-protein nitrogen fraction, producing an apparent protein content of $1.9 \%$. A significant mass fraction of the material $(\sim 29 \%)$ remains to be characterized. The CLMWF powders contained significant quantities of
\end{abstract}

\footnotetext{
* Corresponding author: Mingruo Guo, Department of Nutrition and Food Sciences, University of Vermont, Burlington, VT 05405, USA. Tel: 001-802-656-8168, Fax: 001-802-656-0001, Email: mguo@uvm.edu
} 
calcium, magnesium, phosphorus, potassium and sodium, taurine, L-carnitine, thiamine, and riboflavin, and uridine, cytidine and guanosine based nucleos(t)ides.

\section{Introduction}

Generically defined, milk is the fluid secretion of the female mammary gland; through species-specific adaptations it largely meets the unique nutritional requirements of the neonate of the species. The composition of the secretion is quite dynamic over the period of lactation, reflecting the changing metabolic needs of the offspring from birth through to weaning. Colostrum is somewhat variously defined, as the secretion of the mammary gland produced immediately after parturition (Levieux and Ollier, 1999) or through the first few days after birth (Tsioulpas et al., 2007). The composition of colostrum differs markedly from the mature milk produced later, reflecting a difference in the biological function of the two materials. Bovine colostrum has a much higher total solids content than mature bovine milk $(27.6 \% \mathrm{w} / \mathrm{w}$ vs $12.3 \% \mathrm{w} / \mathrm{w})$, manifested largely in a significantly higher protein content (14.9\% vs $2.8 \%)$ and a slightly higher fat content (6.7\% vs $4.4 \%)$, but it has lower contents of ash $(0.05 \%$ vs $0.8 \%)$ and lactose $(2.5 \%$ vs 4.0\%) (Kehoe et al., 2007; Fox and McSweeney, 2003).

The protein fraction of bovine colostrum has been extensively studied for animal husbandry, nutritional, and economic reasons. Colostrum contains a higher content of whey proteins than mature milk (Levieux and Ollier, 1999), comprised largely of immunoglobulins (Ig), mainly of the $\operatorname{IgG}_{1}$ subclass (Gapper et al., 2007). Ungulate neonates are born essentially agammaglobulinemic (Fox and McSweeney, 2003), and 
substantial amounts of IgG from colostrum are absorbed intact by enterocytes of the jejunum via a non-selective macromolecular transport system. The absorbed $\operatorname{IgG}$ is passed directly into the portal or lymphatic circulation and ultimately confers passive systemic humoral immunity to the ungulate neonate. In contrast, the transfer of passive immunity in humans follows a much different route, with immunoglobulin transfer occurring in utero during the third trimester of pregnancy. Immunoglobulins are found at much lower concentrations in human versus bovine colostrum, primarily in a different form ( $\operatorname{IgA}$ vs $\operatorname{IgG}$ ), and there is no intact absorption to the bloodstream. Nonetheless, the colostral immunoglobulins of both species share at least one function: protecting the cells of the intestine against infection by enteric pathogens (Gapper et al., 2007, Fox and McSweeney, 2003).

The presence of colostrum in the commercial raw milk supply is undesirable, as the whey-dominant proteins in colostrum are more easily denatured than the casein-dominant proteins of mature milk; colostrum proteins denatured by heat treatment cause frequent fouling of thermal processing equipment and the development of off-flavors in dairy products. Accordingly, much of the historical analytical research on bovine colostrum centered on detecting its presence in raw milk supplies, from which it is excluded by statute in most jurisdictions (Levieux and Ollier, 1999). More recently, the application of commercial ultrafiltration (UF) to bovine colostrum has resulted in the creation of powdered food ingredients which contain as much as $80 \%(\mathrm{w} / \mathrm{w})$ protein and $50 \%(\mathrm{w} / \mathrm{w})$ IgG. The obvious difference in Ig form notwithstanding, bovine colostrum-derived IgG concentrates intended for human consumption have an annual market of at least $\$ 100 \mathrm{M}$ 
USD (Gapper et al., 2007), with the material used as a dietary supplement ingredient in sachets, capsules, tablets, and liquid supplements (Mehra et al., 2006) and as an infant formula ingredient. This market for IgG concentrates has transformed bovine colostrum from an agricultural by-product into a valuable raw material. The general process used to create powdered $\operatorname{IgG}$ concentrates from colostrum begins with batch pasteurization, followed by de-fatting, de-caseination, and selective ultrafiltration to concentrate Ig; the protein-containing UF retentate is then spray dried to create a stable, low moisture powder.

The UF process typically uses membranes with $5 \mathrm{kDa}$ to $10 \mathrm{kDa}$ cutoff, thus also creating a liquid permeate which contains the low molecular weight compounds of the colostrum. This material, the colostrum low molecular weight fraction (CLMWF), is viewed as a by-product of IgG production, but may also be dried to create a stable, low moisture powder which is potentially suitable in its own right for use as a food ingredient or dietary supplement. Based on their higher molecular weights, certain antioxidants (lactoferrin), and antioxidant enzymes (lactoperoxidase, catalase, superoxide dismutase, glutathione peroxidase) found in colostrum (Przybylska et al., 2007) would be expected to be found with the Ig in the UF retentate. However, lower molecular weight water soluble substances (vitamins and nutrients, minerals, oligosaccharides, growth factors) if present in the colostrum, will be concentrated in the CLMWF. To the authors' knowledge, there is no published research establishing the basic chemical composition and nutrient profile of a powdered CLMWF made from de-fatted, de-caseinated bovine colostrum. 


\section{Materials and methods}

Distilled, deionized water was used throughout where "water" is specified.

\subsection{Samples}

Samples (200g) of powdered CLMWF from five different production lots were obtained from Sterling Technology (Brookings, SD, USA; trade name Immunel®). The colostrum used as the raw material in the production process was collected within the first 12 hours after parturition, from at most two milkings, from dairy herds across the mid-western United States and was pooled prior to processing as described above for the manufacture of an IgG concentrate from the UF retentate. A representative portion of the UF permeate obtained from each process run was freeze dried to obtain powdered CLMWF.

\subsection{Gross composition}

Gross composition of the samples was determined as follows. All analyses were performed in duplicate. Fat content was determined gravimetrically according to AOAC 989.05 Modified Mojonnier Ether Extraction Method (Horwitz and Latimer, 2006), using a $2 \mathrm{~g}$ powdered sample, which was dissolved in water, hydrolyzed with weak methanolic aqueous potassium hydroxide, then triple extracted with a mixture of ethyl ether and petroleum ether. The pooled extracts were evaporated and the mass of the residue determined, and used to calculate $\%(w / w)$ fat.

The total nitrogen content of the samples was determined by the combustion or Dumas Method (Simonne and Simonne, 1997) using a Leco (St. Joseph, MI, USA) FP-528 
Nitrogen analyzer. EDTA was used as a calibrant, and unknown analyses were performed using 75 - 250mg portions of powdered sample.

Loss on drying was determined gravimetrically using $1.5-2.0 \mathrm{~g}$ portions of powdered sample, using a Mettler (Columbus, OH, USA) HR73 Halogen Analyzer by drying at $105^{\circ} \mathrm{C}$ to a constant weight, with the loss of mass assumed to correspond to free moisture content.

Ash was determined gravimetrically according to AOAC 930.30 Ash of Dried Milk using $5 \mathrm{~g}$ portions of powdered sample, which were charred on a hotplate then held at $550^{\circ} \mathrm{C}$ for $2.5 \mathrm{~h}$, at which time they were essentially carbon-free. The mass of the residue was determined and used to calculate $\%(w / w)$ ash.

\subsection{Carbohydrate analysis}

Carbohydrate analysis was performed by liquid chromatography (LC) using a partitioning separation on an amine bonded silica column as previously described (Indyk et al., 1996). Duplicate 500mg portions of powdered sample were dissolved in water, and made to a final volume of $100 \mathrm{~mL}$ in $40 \%(\mathrm{v} / \mathrm{v})$ methanol. A portion of the solution was filtered through a $0.45 \mu \mathrm{m}$ nylon syringe filter, and an aliquot $(20 \mu \mathrm{L})$ of the filtrate injected onto a liquid chromatography system equipped with a YMC-Pack PA column

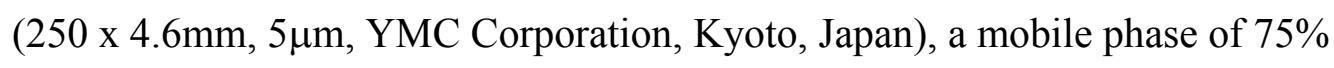

acetonitrile : $25 \%$ water $(\mathrm{v} / \mathrm{v})$ at $1 \mathrm{~mL} \mathrm{~min}^{-1}$, and refractive index (RI) detection. Quantification was achieved by comparison of sample peak response to that of a lactose monohydrate standard of known concentration concomitantly prepared and injected 
under the same conditions. To verify the accuracy of the lactose quantification, additional replicate solutions were prepared from three of the five sample powders, to which a known mass of lactose standard was added in order to characterize the quantitative analytical recovery of the compound: recovery of this added standard averaged 103\%. Under the chromatographic conditions described, clear separation was obtained between mono- and di-saccharides, and the di-saccharides sucrose, maltose, and lactose (retention times $8.1,9.6$, and $10.6 \mathrm{~min}$, respectively) were resolved to baseline. In addition, the run time for sample injections was increased to as much as $40 \mathrm{~min}$, allowing the presumed elution positions of trioses and tetroses to be observed.

Confirmatory carbohydrate analyses for mono- and di-saccharides were performed by Covance Laboratories (Madison, WI, USA) using a gas chromatographic (GC) analysis previously described (Mason and Slover, 1971).

\subsection{Characterization of proteins}

Residual $\operatorname{IgG}$ in the sample powders was analyzed by affinity chromatography on a Protein G column as previously described (Copestake et al., 2006). Powdered samples $(10 \mathrm{~g}, 15 \mathrm{~g}$, and $20 \mathrm{~g})$ were dissolved in $50 \mathrm{~mL} 150 \mathrm{mM}$ sodium chloride then made to final volume $(100 \mathrm{~mL})$ with $200 \mathrm{mM}$ sodium acetate $(\mathrm{pH} 2.95)$. An aliquot of this solution was filtered and injected $(100 \mu \mathrm{L})$ onto a liquid chromatograph equipped with a binary solvent delivery system, a 1mL HiTrap Protein G column (GE Life Sciences, Piscataway, NJ, USA), and ultraviolet detection at $280 \mathrm{~nm}$. Quantification was achieved by comparison of 
sample peak area to that of a bovine IgG standard of known concentration injected under the same conditions.

In a separate experiment, the samples were qualitatively scanned for residual milk proteins using size exclusion chromatography (SEC) on a TSK-Gel $\mathrm{SW}_{\mathrm{XL}}$ column $(7.8 \mathrm{~mm} \times 30 \mathrm{~cm}$, Tosoh Bioscience, Kyoto, Japan) using a mobile phase of $700 \mathrm{~mL}$ water : $300 \mathrm{~mL}$ acetonitrile : $0.1 \mathrm{~mL}$ TFA and ultraviolet detection at $214 \mathrm{~nm}$. Sample powders were dissolved at $1 \mathrm{mg} / \mathrm{mL}$ in mobile phase, and $20 \mu \mathrm{L}$ injected into the chromatographic system. The general relationship between retention time and molecular weight was established by injecting a series of compounds with known molecular weights, and the specific elution positions of the milk proteins glycomacropeptide (GMP, $8 \mathrm{kDa}$ ), $\alpha$ lactalbumin $(14 \mathrm{kDa})$, and $\beta$-lactoglobulin $(18 \mathrm{kDa})$, were determined by preparing solutions $(2 \mathrm{mg} / \mathrm{mL})$ from the authentic compounds and injecting these under identical conditions.

\subsection{Non-Protein Nitrogen (NPN) determination}

NPN content of two samples was determined on the basis of the relative portion of nitrogen which remained soluble in $12 \%(\mathrm{w} / \mathrm{v})$ trichloroacetic acid (TCA). NPN determination was performed by dissolving $50 \mathrm{~g}$ of powdered sample in $100 \mathrm{~mL}$ water, then mixing $10 \mathrm{~mL}$ portions of this solution with either $10 \mathrm{~mL}$ additional water or $10 \mathrm{~mL}$ $24 \%(\mathrm{w} / \mathrm{v})$ TCA. The resulting $12 \%$ TCA solution was filtered, and the filtrate collected. A $12 \%$ TCA reagent blank was prepared using $10 \mathrm{~mL}$ water and $10 \mathrm{~mL} 24 \%$ TCA. Nitrogen determination was performed in duplicate on all solutions as described above. 
The percentage of NPN was calculated as the ratio of the nitrogen content of the filtrate of the $12 \%$ TCA sample solution (corrected for $\% \mathrm{~N}$ in the $12 \%$ TCA reagent) divided by the nitrogen content of the sample solution prepared by diluting $10 \mathrm{~mL}$ of the stock with $10 \mathrm{~mL}$ water.

\subsection{Mineral analysis}

The residue resulting from the ash determination described above was subsequently used for the analysis of minerals by inductively coupled plasma - atomic emission spectroscopy (ICP - AES). The carbon-free ash residue in the crucible was completely dissolved in $2 \mathrm{~mL}$ ultra pure nitric acid with warming, then this solution was quantitatively transferred to $100 \mathrm{~mL}$ acid-washed volumetric flask and diluted to volume with water. This sample preparation is essentially identical to that described in AOAC 985.35, Minerals in Infant Formula, Enteral Products, and Pet Food; subsequent quantification was performed as described in AOAC 984.27, Calcium, Copper, Iron, Magnesium, Manganese, Phosphorous, Potassium, Sodium and Zinc in Infant Formula, except that the $\mathrm{Mg}$ emission line at 279.0nm was used.

\subsection{Water soluble vitamin analysis}

Taurine was determined according to AOAC 997.05 Taurine in Powdered Milk and Powdered Infant Formulae, using a $3 \mathrm{~g}$ portion of powdered sample. Briefly, the powder was reconstituted in water, treated with Carrez 1 and 2 reagents (prepared as described in the referenced method) to precipitate protein, and made to a final volume of $100 \mathrm{~mL}$. The 
solution was then filtered, and an aliquot of the filtrate treated with dansyl chloride to form a taurine derivative. The derivative was quantified by reversed phase liquid chromatography using a Waters (Milford, MA, USA) Resolve $\mathrm{C}_{18}$ column (3.9 x 150mm, $5 \mu \mathrm{m}$ ) and UV detection at $254 \mathrm{~nm}$, by comparison of its area to that of a standard solution of known taurine concentration similarly derivatized.

Thiamine, pyridoxine, riboflavin, and niacinamide were determined individually by reversed phase liquid chromatography according to a previously described method (Woollard and Indyk, 2002), using 10 - 20g portions of powdered sample, reconstituted in water and treated with acetic acid (for thiamine determination) or trichloroacetic acid (for the other three vitamins) to precipitate protein. The resulting solution was filtered, and the individual vitamins quantified by reversed phase liquid chromatography using optimized separation and detection mechanisms.

Total L-carnitine was determined by LC MS/MS (Starkey et al., 2008) at Covance Laboratories.

\subsection{Nucleotide and nucleoside analysis}

Nucleosides were determined by a previously described liquid chromatographic method (Olivartes and Verdys, 1988) at Covance Laboratories. Nucleotide content of the powdered samples was determined by liquid chromatography. Samples were prepared by dissolving a $20 \mathrm{~g}$ portion of powdered sample in $100 \mathrm{~mL}$ water and injecting an aliquot $(20 \mu \mathrm{L})$ into an isocratic reversed phase chromatographic system using a YMC ODS AQ312 column $(150 \times 6.0 \mathrm{~mm}, 4 \mu \mathrm{m})$, a mobile phase of $0.1 \mathrm{M}$ potassium dihydrogen 
phosphate ( $\mathrm{pH} 5.6)$ and ultraviolet detection at 254nm. Quantification was performed by comparison of sample peak areas to those of individual nucleotide standards of known concentration injected under the same conditions.

\subsection{Amino acid analysis}

Total amino acids were analyzed by Covance Laboratories. Tryptophan was determined by AOAC 982.30, Protein Efficiency Ratio, cystine was determined by ion chromatography with post-column derivitization (Barkholt and Jensen, 1989), and 16 other amino acids were determined by reversed phase chromatography after pre-column derivitization (Schuster, 1988).

\subsection{Physical properties}

The $\mathrm{pH}$ of a $10 \%(\mathrm{w} / \mathrm{v})$ solution of each sample, prepared in $\mathrm{CO}_{2}$-free water, was measured at $25^{\circ} \mathrm{C}$ using a digital $\mathrm{pH}$ meter calibrated at $\mathrm{pH} 4.00$ and 7.00 with commercially available buffers. The color and clarity of each solution was also recorded.

\section{Results and discussion}

As described above, low moisture powdered samples of CLMWF were produced by freeze drying the permeate obtained from the $5 \mathrm{kDa}$ cutoff ultrafiltration (UF) of defatted, de-caseinated bovine colostrum. Based on their similar methods of manufacture, the composition of powdered CLMWF bears comparison to whey permeate (WP), the byproduct obtained from the similar UF process used in the manufacture of whey protein powders from liquid whey. The composition of powdered CLMWF may also be 
compared to mature bovine milk and bovine colostrum, although relatively little analytical data has been published on the chemical composition of the latter. While the analyses performed in this work were done on low moisture powders, many of the literature values for whey permeate, bovine colostrum and mature bovine milk are expressed on a per liter (liquid) basis, making direct comparison of the quantitative values of little value. Therefore in the discussion below, to facilitate direct comparison of these materials, literature values stated on a per liter basis are converted to a " $98 \%$ solids basis", as if these materials had been directly spray dried to create low moisture powders.

\subsection{Carbohydrate profile}

The mean lactose (as monohydrate) content of the powdered CLMWF samples determined by LC was $58.2 \%(\mathrm{w} / \mathrm{w})$ (standard deviation $1.7 \%$, w/w). In the authors' experience, due to the relative insensitivity of refractive index detection, the limit of quantification for mono- and di-saccharides using the method described is typically $0.5 \%$ $(w / w)$; none of the sample chromatograms showed measurable peaks corresponding to glucose, galactose, fructose, maltose, or sucrose. In addition, inspection of the overlaid sample chromatograms failed to reveal any consistent peaks which might correspond to trioses or tetroses, however in the authors' experience the method described would lack the sensitivity to detect these compounds below $\sim 5 \%(\mathrm{w} / \mathrm{w})$. The confirmatory carbohydrate results obtained by GC were similar, showing a mean lactose content of $60.2 \%(\mathrm{w} / \mathrm{w})($ standard deviation $0.92 \%, \mathrm{w} / \mathrm{w})$, responses below the limit of detection 
$(<0.1 \% \mathrm{w} / \mathrm{w})$ for glucose, fructose, maltose and sucrose, and an average result of $0.4 \%$ $(\mathrm{w} / \mathrm{w})$ for galactose.

\subsection{Gross composition}

The gross composition of powdered CLMWF is shown in Table 9. The total nitrogen content of the material averaged $1.13 \% \mathrm{w} / \mathrm{w}$, and as described below, $74 \%$ of this nitrogen was found to reside in the non-protein nitrogen (NPN) fraction. The true protein content of CLMWF may be calculated by applying the nitrogen-to-protein conversion factor for milk protein (6.38) to the complementary protein nitrogen percentage (26\%), to yield a value of $1.9 \% \mathrm{w} / \mathrm{w}$. As shown in Table 9 , the known gross components of powdered CLMWF account for $\sim 71 \% \mathrm{w} / \mathrm{w}$ of the material, leaving $\sim 29 \% \mathrm{w} / \mathrm{w}$ to be characterized.

\subsection{Comparison of CLMWF gross composition to milk, colostrum, and whey permeate}

The gross composition of fluid mature bovine milk is reported as $12.7 \%(\mathrm{w} / \mathrm{v})$ solids, of which $4.5 \%$ is fat, $2.9 \%$ protein, $4.1 \%$ lactose and $0.8 \%$ ash (Fox and McSweeney, 2003). To facilitate direct comparison to powdered CLMWF, these values may be expressed on a $98 \%$ solids powder basis, yielding values of $2.0 \%(\mathrm{w} / \mathrm{w})$ moisture, $34.7 \%$ fat, $22.4 \%$ protein, $31.6 \%$ lactose and $6.2 \%$ ash, totaling $96.9 \%$, with the balance of the solids $(\sim 3.0 \%)$ comprised of non-protein nitrogen compounds. Similar calculations were performed using recently published data for bovine colostrum reported at $27.6 \%$ solids (Kehoe et al., 2007) assuming $1.06 \mathrm{~g} / \mathrm{mL}$, and whey permeate reported at $7 \%$ solids 
(Beucler et al., 2005) assuming 1.03g/mL. Table 10 compares the gross composition of powdered CLMWF, mature bovine milk, bovine colostrum, and selected examples of whey permeate. Based on the materials' similar means of manufacture, the composition of powdered CLMWF is somewhat similar to whey permeate, although it contains lower levels of protein, lactose and fat.

As shown in Table 10 and outlined above, the known gross components (moisture, fat, ash, lactose, protein) of mature bovine milk (as a powder) account for $\sim 97 \% \mathrm{w} / \mathrm{w}$ of the material. Table 10 shows that the known gross components of bovine colostrum (as a powder) account for $\sim 88 \% \mathrm{w} / \mathrm{w}$ of this material, and as outlined above, the known gross components of powdered CLMWF account for only $\sim 71 \% \mathrm{w} / \mathrm{w}$ of this material. The CLMWF was not analyzed for oligosaccharides, but their potential abundance may be estimated based on previously published research (McJarrow and van AmeslfortSchoonbeek, 2004), showing total sialyloligosaccharides (SOS) to be present in colostrum at $\sim 5 \%$ of the level of lactose (expressed on a common basis, $\sim 140 \mathrm{mg} / 100 \mathrm{~g}$ SOS to $\sim 3 \mathrm{~g} / 100 \mathrm{~g}$ lactose). Assuming no discrimination against oligosaccharides by the UF membrane, the lactose content of $\sim 60 \% \mathrm{w} / \mathrm{w}$ in powdered CLMWF would predict an oligosaccharide content of $\sim 3 \% \mathrm{w} / \mathrm{w}$, thus accounting for only a fraction of the unknown material.

\subsection{Protein profile}

The affinity chromatography analysis revealed that the powdered CLMWF contained reproducible amounts of IgG, averaging $10 \mathrm{mg} / 100 \mathrm{~g}$, or $0.01 \%(\mathrm{w} / \mathrm{w})$. All replicates 
analyzed showed results between 9 and $12 \mathrm{mg} / 100 \mathrm{~g}$; at this level the chromatograms showed a signal-to-noise ratio for the peak of interest of at least 20:1. The SEC analysis failed to detect any peaks in the samples in the range of $20 \mathrm{kDa}-0.5 \mathrm{kDa}$, with a notable absence of response at the demonstrated retention times of glycomacropeptide, $\alpha$ lactalbumin, and $\beta$-lactoglobulin, (data not shown).

\subsection{Non-Protein Nitrogen (NPN) and amino acids}

NPN is defined as the nitrogen-containing compounds remaining soluble in $12 \%(\mathrm{w} / \mathrm{v})$ TCA (Fox and McSweeney, 2003). Following the methodology described above, on average, the CLMWF sample solutions in water contained $0.219 \%$ nitrogen, while the filtrate of the sample solutions from $12 \%$ TCA contained $0.162 \%$ nitrogen (after correction for nitrogen in the TCA reagent); thus on average, $74 \%$ of the nitrogen was found in the NPN fraction with the complementary $26 \%$ nitrogen assumed to be in the protein nitrogen fraction. In mature bovine milk, the distribution of nitrogen is $78 \%$ in casein, $12 \%$ in lactalbumin, $5 \%$ in lactoglobulin, and $2 \%$ in proteose peptone (totaling 97\%), leaving only 3\% in non-protein NPN (Fox and McSweeney, 2003). A nitrogen-toprotein factor of 1.66 can be applied to this CLMWF, based on the nitrogen to protein conversion factor for milk (6.38) and the portion of the nitrogen assumed to occur as true protein in the material studied $(26 \%)$.

The results of the amino acid analyses are shown in Table 11, and can be used to produce an independent estimate of nitrogen distribution between protein and NPN fractions. Dividing the sum of the amino acids (in $\mathrm{mg} / 100 \mathrm{~g}$ powdered CLMWF) by the 
nitrogen-to-protein ratio for milk (6.38) yields an estimate of the nitrogen content of the sample contained in the amino acids, and this value may be taken as the protein nitrogen content under the assumption that all amino acids are contained in proteins. Dividing this quantity by the total nitrogen of the sample (also in $\mathrm{mg} / 100 \mathrm{~g}$ powdered CLMWF) thus produces an estimate of the protein nitrogen percentage, with the complementary portion of nitrogen assumed to be NPN. As shown in Table 11, the portion of nitrogen in the protein fraction may thus be calculated at $33 \%-38 \%$, with the complementary $62-67 \%$ nitrogen lying in the NPN fraction.

The mean protein nitrogen calculated from the amino acid composition data $(36 \%)$ is higher than that that predicted by the complement of the direct NPN analysis $(26 \%)$, possibly indicating the presence of low molecular weight proteins (such as insulin-like growth factors) or peptides which are not precipitated by $12 \%$ TCA and thus are detected as apparent NPN.

Further analytical work is necessary to detect and quantify low molecular weight proteins or peptides in CLMWF, however, in general, the NPN content of the material is much high higher than mature bovine milk, due to the increased abundance of small, nitrogen-containing molecules with nutrient activity as shown below.

\subsection{Minerals and water soluble vitamins}

The results of mineral and water soluble vitamin analyses on the powdered CLMWF are shown in Table 12. Although significant variation was noted in the content of low abundance micronutrients, in general, the compositional variability of nutrients decreased 
as their mass fraction increased. Table 12 also contains recently published values for vitamins and minerals in liquid bovine colostrum (Kehoe et al., 2007) and whey permeate (Beucler et al., 2005), expressing the published values on a $98 \%$ dry matter basis as described above, and values for a whey permeate powder (Boumba et al., 2001.)

In general, small water soluble molecules and free ions appeared to migrate to the UF permeate used to create the CLMWF, presumably producing a corresponding depletion of the UF retentate, and an overall concentration effect in the CLMWF relative to bovine colostrum. The concentration effect was not noted for calcium, which might tend to associate with proteins and remain in the UF retentate, or for phosphorus. Relative to bovine colostrum, the CLMWF had higher contents of freely soluble ions (sodium, potassium), and small nutrient molecules (thiamine, pyridoxine, niacinamide, riboflavin, and nucleos(t)ides, as described below). By way of more general comparison, the average taurine content of powdered CLMWF $(26.6 \mathrm{mg} / 100 \mathrm{~g})$ was noted to be higher than published values obtained by a similar analytical method (Woollard and Indyk, 1993) for wholemilk powder $(4.3 \mathrm{mg} / 100 \mathrm{~g})$ and whey protein concentrate powder $(4.3 \mathrm{mg} / 100 \mathrm{~g})$, but only slightly higher than dried whey powder $(18.8 \mathrm{mg} / 100 \mathrm{~g})$. Other recent data (Ferreira, 2003) for whole cow's milk described a taurine level of $10.7 \mathrm{mg} / 100 \mathrm{~g}$ when converted to a $98 \%$ dry matter basis as described above. The average L-carnitine content of powdered CLMWF $(40.5 \mathrm{mg} / 100 \mathrm{~g})$ was noted to be slightly higher than that of cow's milk from this same reference when expressed in the same manner $(31.5 \mathrm{mg} / 100 \mathrm{~g})$. 


\subsection{Nucleotide and nucleoside content}

Nucleosides and nucleotides belong to the non-protein nitrogen fraction of milk. A pyrimidine or purine base esterified to the sugar ribose forms a nucleoside; the corresponding nucleotide is formed by subsequent esterification to phosphoric acid through the 5 carbon of ribose. Although the compounds are present in small quantities in milk and colostrum, it is believed their overall and relative abundances form a species specific adaptation with specific physiological consequences. Aside from their role in DNA and RNA synthesis, nucleosides and their corresponding nucleotides are believed to enhance a wide variety of physiological functions, including iron absorption in the gut, increased rate of synthesis of long chain polyunsaturated fatty acids (LCPUFA), and enhanced immune response through increased antibody formation (Schlimme et al., 2000).

The concentrations of nucleos $(\mathrm{t})$ ides in both human and bovine milk and colostrum has been extensively studied, as summarized previously (Schlimme et al., 2000). For comparison to the values obtained in powdered CLMWF, values for milk and colostrum were expressed on a $98 \%$ dry matter basis as described above. Table 13 presents the results of the nucleoside and nucleotide analyses of the powdered CLMWF, along with comparisons to human milk, bovine milk, and bovine colostrum.

In general, the concentration effect noted above for small, soluble molecules in the CLMWF relative to bovine colostrum extended to the nucleoside content of the material, but not to the nucleotide content. Overall, CLMWF is a fairly rich source of these 
compounds. For nucleosides, the powdered CLMWF showed higher values than bovine milk or colostrum for cytidine, uridine, guanosine and inosine, although the pattern did not hold for adenosine. For the corresponding nucleotides, the powdered CLMWF exhibited values similar to bovine colostrum for 5'CMP, 5'UMP and 5'AMP, thus failing to show a concentration effect. In this research, a small amount of 5'GMP was detected in the powdered CLMWF, in contrast to literature values for bovine milk and colostrum.

\subsection{Physical properties}

The $10 \%(\mathrm{w} / \mathrm{v})$ solutions of powdered CLMWF in $\mathrm{CO}_{2}$-free water showed an average $\mathrm{pH}$ of 3.22 (range $3.18-3.30$ ); in practice the measurements were made between $24.8^{\circ} \mathrm{C}-$ $26.7^{\circ} \mathrm{C}$. All solutions were yellow in color; four of the five samples produced clear solutions, while the fifth was noted to be slightly hazy.

\section{Conclusions}

As a result of the extensive processing it undergoes, the general chemical composition of powdered CLMWF is similar to whey permeate, and quite different from bovine colostrum or mature milk. Powdered CLMWF is highly soluble in water and contains significant quantities of several minerals, water soluble vitamins, and nucleos(t)ides, as well as relatively high levels of taurine and L-carnitine. The low molecular weight fraction of colostrum may represent a unique functional food ingredient that bears further investigation to completely understand the composition of its growth factors, peptides, and carbohydrate fraction (including oligosaccharides). 


\section{Acknowledgements}

The authors thank Covance Laboratories (Madison, WI) for invaluable assistance by

performing the analyses of selected compounds, with special thanks to Wayne Ellefson.

\section{References}

Barkholt, V. and A. L. Jensen, 1989. Amino Acid Analysis: Determination of Cystine Plus Half-Cystine in Proteins After Hydrochloric Acid Hydrolysis with a Disulfide Compound as Additive. Analytical Biochemistry, 177, 318-322.

Beucler, J., M. Drake, and E. A. Foegeding, 2005. Design of a beverage from whey permeate. Journal of Food Science, 70(4), S277 - S285.

Boumba, V.A., L.P. Voutsinas, C.D. Philippopoulos, 2001. Composition and nutritional value of commercial dried whey products from feta cheese manufacture. International Journal of Dairy Technology, 54(4), 141-145.

Copestake, D. E. J., H. E. Indyk, D.E. Otter, 2006. Affinity liquid chromatography method for the quantification of immunoglobulin $\mathrm{G}$ in bovine colostrum powders. Journal of AOAC International, 89, 1249-1256.

Ferreira, I. M. P. L. V. O., 2003. Quantification of non-protein nitrogen components of infant formulae and follow-up milks: comparison with cows' and human milk. British Journal of Nutrition, 90, 127-133.

Fox, P. F. and P. L. H. McSweeney, 2003. Advanced Dairy Chemistry - Volume 1 Proteins, Third Edition, Part A. New York, New York, USA: Kluwer Academic / Plenum Publishers.

Gapper, L. W., D. E. J. Copestake, D.E. Otter, H. E. Indyk, 2007. Analysis of bovine immunoglobulin $\mathrm{G}$ in milk, colostrum and dietary supplements: a review. Analytical and bioanalytical chemistry, 389, 93-109.

Horwitz, W., and G. Latimer Jr., Editors, 2006. Official Methods of Analysis of AOAC International, $18^{\text {th }}$ Edition, Revision 1. AOAC International, Gaithersburg, MD.

Indyk, H. E., M. J. Edwards, D.C. Woollard, 1996. High performance liquid chromatographic analysis of lactose-hydrolysed milk. Food chemistry, 57(4), 575 580.

Kehoe, S. I., B.M. Jayarao, A. J. Heinrichs, 2007. A survey of bovine colostrum composition and colostrum management practices on Pennsylvania dairy farms. Journal of Dairy Science, 90, 4108-4116.

Levieux, D. and A. Ollier, 1999. Bovine immunoglobulin G, beta-lactoglobulin, alphalactalbumin and serum albumin in colostrum and milk during the early post partum period. Journal of Dairy Research, 66(3), 421-430. 
Mason, B. S. and H. T. Slover, 1971. A gas chromatographic method for the determination of sugars in foods. Journal of Agricultural Food Chemistry, 19(3), 551-554.

McJarrow, P. and J. van Amelsfort-Schoonbeek, 2004. Bovine sialyl oligosaccharides: seasonal variations in their concentrations in milk, and a comparison of the colostrums of Jersey and Friesian cows. International Dairy Journal, 14, 571-579.

Mehra, R., P. Marnila, H. Kornhonen, 2006. Milk immunoglobulins for health promotion. International Dairy Journal, 16(11), 1262-1271.

Olivartes, J. and M. Verdys, 1988. Isocratic high performance liquid chromatographic method for studying the metabolism of blood plasma pyrimidine nucleosides and bases. Journal of Chromatography, 434.

Przybylska, J., E. Albera and M. Kankofer, 2007. Antioxidants in bovine colostrum. Reproduction of Domestic Animals, 42, 402 - 409.

Schlimme, E., D. Martin, H. Meisel, 2000. Nucleosides and nucleotides: natural bioactive substances in milk and colostrum. British Journal of Nutrition, 84 (suppl.1), s59s68.

Schuster, R, 1988. Determination of amino acids in biological, pharmaceutical, plant, and food samples by automated precolumn derivitization and HPLC. Journal of Chromatography, 431, 271-284.

Simonne, A. H., E. H. Simonne, 1997. Could the Dumas method replace the Kjeldahl digestion for nitrogen and crude protein determinations in foods? Journal of the Science of Food and Agriculture, 73(1): 39-45.

Starkey, D. E., J. E. Denison, C.T. Seipelt, W.A. Jacobs, 2008. Single-laboratory validation of a liquid chromatographic/tandem mass spectrometric method for the determination of free and total carnitine in infant formula and raw ingredients. Journal of AOAC International, 91, 130-142.

Tsioulpas, A., Grandison, A. S., Lewis, M., J., 2007. Changes in physical properties of bovine milk from the colostrum period to early lactation. Journal of Dairy Science, 90(11), 5012-5017.

Woollard, D. C. and H. E. Indyk, 1993. The determination and distribution of taurine in dairy products. Food Chemistry, 46, 429-437.

Woollard, D. C. and H. E. Indyk, 2002. Rapid determination of thiamine, riboflavin, pyridoxine, and niacinamide in infant formulas by liquid chromatography. Journal of AOAC International, 85(4), 945-951. 
Table 9. Gross composition of powdered CLMWF

\begin{tabular}{|c|c|c|c|c|c|}
\hline \multicolumn{6}{|c|}{ All values in $\%(\mathrm{w} / \mathrm{w})$, means of duplicate analyses reported } \\
\hline & Moisture & Nitrogen $^{c}$ & Fat & Ash & Lactose \\
\hline Mean & $1.73 \%$ & $1.13 \%$ & $0.60 \%$ & $8.31 \%$ & $58.2 \%$ \\
\hline $\mathrm{SD}^{\mathrm{a}}$ & $0.55 \%$ & $0.03 \%$ & $0.14 \%$ & $0.25 \%$ & $1.7 \%$ \\
\hline $\mathrm{RSD}^{\mathrm{b}}$ & $32.0 \%$ & $2.7 \%$ & $23.3 \%$ & $3.0 \%$ & $2.9 \%$ \\
\hline \multicolumn{6}{|c|}{$\begin{array}{l}{ }^{\mathrm{a}} \mathrm{SD}=\text { standard deviation } \\
\mathrm{b} \text { RSD = relative standard deviation: }(\mathrm{SD} / \mathrm{Mean}) \times 100 \% \\
{ }^{\mathrm{c}} \text { As described in the text, } 1.13 \% \text { nitrogen } \times(100 \%-74 \% \mathrm{NPN}) \times 6.38= \\
1.9 \% \text { protein }\end{array}$} \\
\hline
\end{tabular}


Table 10. Comparison of gross fractions of powdered CLMWF, bovine milk, bovine colostrum, and whey permeate

\begin{tabular}{|c|c|c|c|c|c|}
\hline \multicolumn{6}{|c|}{ All values in $\%(\mathrm{w} / \mathrm{w})$} \\
\hline Matrix & Moisture & Protein & Fat & Ash & Lactose \\
\hline CLMWF $^{\mathrm{a}}$ & $1.7 \%$ & $1.9 \%$ & $0.6 \%$ & $8.3 \%$ & $58.2 \%$ \\
\hline Milk $^{\mathrm{b}}$ & $2.0 \%$ & $22.4 \%$ & $34.7 \%$ & $6.2 \%$ & $31.6 \%$ \\
\hline Colostrum $^{\mathrm{b}}$ & $2.0 \%$ & $52.9 \%$ & $23.8 \%$ & $0.2 \%$ & $8.8 \%$ \\
\hline Whey permeate $^{\mathrm{c}}$ & $2.0 \%-2.5 \%$ & $5-11.9 \%$ & $0.1-5.0 \%$ & $7.4 \%-8.1 \%$ & $70.0 \%-82.2 \%$ \\
\hline $\begin{array}{l}{ }^{\mathrm{a}} \text { Values for } \mathrm{C} \\
{ }^{\mathrm{b}} \text { Values for } \mathrm{b} \\
\text { (Kehoe et } \\
{ }^{\mathrm{c}} \text { Values for } \\
\text { (presented } \mathrm{p}\end{array}$ & $\begin{array}{l}\text { LWF from T } \\
\text { ne milk (Fo } \\
\text { 2007) pres } \\
\text { y permeate } \\
100 \mathrm{~g} \text { powde }\end{array}$ & $\begin{array}{l}\text { ble } 8 \text { (shor } \\
\text { and McSu } \\
\text { ted per } 10 \\
\text { own as a r } \\
\text { basis as de }\end{array}$ & $\begin{array}{l}\text { to one de } \\
\text { eney, } 200 \\
g \text { powder } \\
\text { ige based } \\
\text { cribed in } t\end{array}$ & $\begin{array}{l}\text { Imal here). } \\
\text { and bovine } \\
\text { sis as descri } \\
\text { Beucler at } \\
\text { t) and Boun }\end{array}$ & $\begin{array}{l}\text { lostrum } \\
\text { in text. } \\
\text {., } 2005 \\
\text { a et al., } 2001 \text {. }\end{array}$ \\
\hline
\end{tabular}


Table 11. Amino acid composition of powdered CLMWF

\begin{tabular}{|c|c|c|c|c|c|c|c|c|}
\hline Lot & 1 & 2 & 3 & 4 & 5 & Mean $^{a}$ & $\mathrm{SD}^{\mathrm{a}}$ & RSD \\
\hline Asp & 149 & 168 & 186 & 158 & 194 & 171 & 18.8 & $11 \%$ \\
\hline Thr & 77.6 & 92.2 & 100 & 80.7 & 99.5 & 90 & 10.4 & $12 \%$ \\
\hline Ser & 100 & 116 & 122 & 103 & 119 & 112 & 9.9 & $9 \%$ \\
\hline Glu & 458 & 541 & 472 & 427 & 476 & 475 & 41.7 & $9 \%$ \\
\hline Pro & 214 & 263 & 234 & 222 & 234 & 233 & 18.6 & $8 \%$ \\
\hline Gly & 104 & 96.6 & 119 & 105 & 114 & 107.7 & 8.8 & $8 \%$ \\
\hline Ala & 99.3 & 107 & 107 & 99.8 & 105 & 103.6 & 3.8 & $4 \%$ \\
\hline Val & 292 & 303 & 340 & 339 & 325 & 320 & 21.6 & $7 \%$ \\
\hline Iso & 99.2 & 124 & 117 & 105 & 119 & 113 & 10.3 & $9 \%$ \\
\hline Leu & 165 & 210 & 190 & 178 & 195 & 188 & 17.1 & $9 \%$ \\
\hline Tyr & 82.0 & 95.4 & 91.6 & 85.4 & 94.4 & 89.8 & 5.8 & $6 \%$ \\
\hline Phe & 93.8 & 114 & 108 & 104 & 107 & 105 & 7.4 & $7 \%$ \\
\hline Lys & 137 & 161 & 150 & 134 & 151 & 147 & 11.1 & $8 \%$ \\
\hline His & 51.8 & 64.5 & 37.1 & 41.3 & 38.1 & 46.6 & 11.6 & $25 \%$ \\
\hline Arg & 191 & 170 & 146 & 149 & 146 & 160 & 19.8 & $12 \%$ \\
\hline Cys & 18.3 & 14.1 & 19.8 & 13.6 & 20.0 & 17.2 & 3.1 & $18 \%$ \\
\hline Met & 54.9 & 63 & 59.1 & 56.0 & 55.2 & 57.6 & 3.4 & $6 \%$ \\
\hline Try & 41.9 & 40 & 32.9 & 25.2 & 34.5 & 34.9 & 6.6 & $19 \%$ \\
\hline Total $\mathrm{AA}^{\mathrm{a}}$ & 2429 & 2743 & 2632 & 2426 & 2627 & 2571 & 139 & $5 \%$ \\
\hline AA N ${ }^{b}:$ & 381 & 430 & 412 & 380 & 412 & 403 & 22 & $5 \%$ \\
\hline Total $\mathrm{N}^{\mathrm{c}}$ & 1150 & 1130 & 1160 & 1090 & 1100 & 1130 & - & - \\
\hline AA N / Total N ${ }^{d}$ & $33 \%$ & $38 \%$ & $36 \%$ & $35 \%$ & $37 \%$ & $36 \%$ & - & - \\
\hline \multicolumn{9}{|c|}{$\begin{array}{l}\text { a All individual, mean, and total amino acid values reported in } \mathrm{mg} / 100 \mathrm{~g} \text { CLMWF } \\
\mathrm{b} \text { Amino Acid Nitrogen (AA N) calculated as Total AA / 6.38, mg/100g CLMWF } \\
\text { Am }{ }^{\mathrm{c}} \text { Total Nitrogen, determined by combustion as described in text, mg/100g CLMWF } \\
\text { d } \text { AA N / Total N = Amino Acid Nitrogen / Total Nitrogen }\end{array}$} \\
\hline
\end{tabular}


Table 12. Nutrient content of powdered CLMWF, and comparison to published values for colostrum and whey permeate

\begin{tabular}{|c|c|c|c|c|c|c|c|}
\hline & & \multicolumn{3}{|c|}{ In powdered CLMWF } & \multirow[b]{2}{*}{$\begin{array}{l}\text { In bovine } \\
\text { colostrum }^{\mathrm{b}}\end{array}$} & \multirow[b]{2}{*}{$\begin{array}{c}\text { In whey } \\
\text { permeate as } \\
\text { powder }^{\mathrm{c}}\end{array}$} & \multirow[b]{2}{*}{$\begin{array}{l}\text { In whey } \\
\text { permeate } \\
\text { powder }^{\text {d }}\end{array}$} \\
\hline Nutrient & Units & Mean & SD & RSD & & & \\
\hline Calcium & \multirow{7}{*}{$\mathrm{mg} / 100 \mathrm{~g}$} & 870 & 105 & $12 \%$ & 1577 & 589 & 370 \\
\hline Iron & & 2.88 & 2.05 & $71 \%$ & 1.78 & $\mathrm{e}$ & $\mathrm{e}$ \\
\hline Magnesium & & 311 & 7.1 & $2.3 \%$ & 245 & 135 & ${ }^{\mathrm{e}}$ \\
\hline Phosphorous & & 1473 & 51 & $3.4 \%$ & 1489 & 759 & 550 \\
\hline Potassium & & 1705 & 107 & $6.3 \%$ & 951 & 3036 & 1800 \\
\hline Sodium & & 690 & 40 & $5.8 \%$ & 354 & 1019 & 700 \\
\hline Zinc & & 0.177 & 0.133 & $75 \%$ & 12.7 & 0.396 & \multirow{9}{*}{$\mathrm{e}$} \\
\hline Copper & \multirow{2}{*}{$\mathrm{mcg} / 100 \mathrm{~g}$} & 52.7 & 36.4 & $69 \%$ & 114 & \multirow{8}{*}{$\mathrm{e}$} & \\
\hline Manganese & & 9.2 & 5.5 & $60 \%$ & 33.4 & & \\
\hline Thiamine $^{\mathrm{a}}$ & \multirow{4}{*}{$\mathrm{mcg} / 100 \mathrm{~g}$} & 648 & 52 & $8.1 \%$ & 301 & & \\
\hline Pyridoxine $^{\mathrm{a}}$ & & 24 & 14.6 & $62 \%$ & 13 & & \\
\hline Niacinamide & & 611 & 140 & $23 \%$ & 114 & & \\
\hline Riboflavin & & 6991 & 1533 & $22 \%$ & 1521 & & \\
\hline Taurine & \multirow{2}{*}{$\mathrm{mg} / 100 \mathrm{~g}$} & 26.6 & 5.8 & $22 \%$ & \multirow{2}{*}{$\mathrm{e}$} & & \\
\hline L-Carnitine & & 40.5 & 1.4 & $3.6 \%$ & & & \\
\hline \multicolumn{8}{|c|}{$\begin{array}{l}\text { a Reported as the free base } \\
\text { b Values for bovine colostrum expressed on per } / 100 \mathrm{~g} \text { powder basis, calculated as described in text using } \\
\text { values from Kehoe et al. (2007) reported at } 27.6 \% \text { total solids and assuming } 1.06 \mathrm{~g} / \mathrm{ml} \\
{ }^{c} \text { Values for whey permeate expressed on per } 100 \mathrm{~g} \text { powder basis, calculated as described in text using } \\
\text { values from Beucler et al. (2005) reported at } 7 \% \text { total solids and assuming } 1.03 \mathrm{~g} / \mathrm{ml} \\
\text { d Values for whey permeate powder from Boumba et al., } 2001 \\
{ }^{\mathrm{e}} \text { Not reported in reference }\end{array}$} \\
\hline
\end{tabular}


Table 13. Nucleosides and nucleotides in powdered CLMWF; comparison to published values for milk and colostrum

\begin{tabular}{|c|c|c|c|c|c|c|}
\hline \multirow[b]{2}{*}{ Compound } & \multicolumn{3}{|c|}{ CLMWF } & \multirow[b]{2}{*}{$\begin{array}{l}\text { Human } \\
\text { Milk }^{\text {b, c }}\end{array}$} & \multirow[b]{2}{*}{$\begin{array}{l}\text { Bovine } \\
\text { Milk }^{\text {b,d }}\end{array}$} & \multirow[b]{2}{*}{$\begin{array}{c}\text { Bovine } \\
\text { Colostrum }\end{array}$} \\
\hline & Mean $^{b}$ & $\mathrm{SD}^{\mathrm{b}}$ & RSD & & & \\
\hline Cytidine & 3.33 & 0.40 & $12.0 \%$ & $0.77-0.93$ & 0.43 & 0.94 \\
\hline 5'CMP & 4.83 & 0.42 & $8.6 \%$ & 5.40 & 4.53 & 3.42 \\
\hline Uridine & 55.2 & 1.10 & $2.0 \%$ & $0.08-1.31$ & 2.66 & 10.7 \\
\hline 5’UMP & 18.8 & 13.4 & $71 \%$ & 3.71 & $\mathrm{ND}^{\mathrm{a}}$ & 22.9 \\
\hline Guanosine & 3.45 & 0.33 & $9.5 \%$ & $0.08-0.23$ & 0.17 & 0.20 \\
\hline 5’GMP & 3.57 & 1.68 & $47 \%$ & 0.93 & $\mathrm{ND}^{\mathrm{a}}$ & $\mathrm{ND}^{\mathrm{a}}$ \\
\hline Inosine & 0.88 & 0.83 & $95 \%$ & $\mathrm{f}$ & 0.20 & 0.42 \\
\hline 5'IMP & $\mathrm{ND}^{\mathrm{a}}$ & - & - & $\mathrm{f}$ & 5 & $f$ \\
\hline Adenosine & $\mathrm{ND}^{\mathrm{a}}$ & - & - & $0.31-1.08$ & 0.28 & 0.18 \\
\hline 5'AMP & 3.23 & 0.27 & $8.4 \%$ & 6.02 & 3.72 & 4.57 \\
\hline \multicolumn{7}{|c|}{$\begin{array}{l}\text { c Values from Schlimme et al. (2000), Tables } 2 \text { and } 4 \mathrm{in} \mathrm{mg} / \mathrm{L} \text { converted to } \\
\mathrm{mg} / 100 \mathrm{~g} \text { powder basis assuming } 12.7 \% \mathrm{w} / \mathrm{v} \text { total solids (Fox and } \\
\text { McSweeney, 2003) and } 1.03 \mathrm{~g} / \mathrm{ml} \text {; three different studies cited, overall range } \\
\text { shown. } \\
\text { d Values from Schlimme et al. (2000), Table } 1 \mathrm{row} \text { "d" and Table } 3 \mathrm{row} \text { "2 } \\
\text { months" in } \mu \mathrm{mol} / \mathrm{L} \text { converted to } \mathrm{mg} / 100 \mathrm{~g} \text { powder basis assuming } 12.7 \% \mathrm{w} / \mathrm{v} \\
\text { total solids and } 1.03 \mathrm{~g} / \mathrm{ml}\end{array}$} \\
\hline
\end{tabular}




\section{Comprehensive Bibliography}

Barkholt, J. (1989). "Amino Acid Analysis: Determination of Cystine Plus Half-Cystine in Proteins After Hydrochloric Acid Hydrolysis with a Disulfide Compound as Additive." Analytical Biochemistry 177: 318-322.

Beucler, J., M. Drake, et al. (2005). "Design of a beverage from whey permeate." Journal of food science 70: s277-s285.

Boulton, A. A., G. B. Baker, et al. (1988). Neuromethods 7: Lipids and Related Compounds. Clifton, NJ, Humana Press.

Boumba, V. A., L. P. Voutsinas, et al. (2001). "Composition and nutritional value of commercial dried whey products from feta cheese manufacture." International Journal of Dairy Technology 54(4): 141-145.

Brandon, M. R., D. L. Watson, et al. (1971). "The Mechanism of Transfer of Immunoglobulin into Mammary Gland Secretion of Cows." Aust. J. exp. Biol. med. Sci. 49: 613-623.

Conessa, C., M. Lavilla, et al. (2005). "Determination of IgG levels in bovine milk samples from different regions of spain." Eur Food Res Technol 220: 222-225.

Copestake, D. E. J., H. E. Indyk, et al. (2006). "Affinity Liquid Chromatography Method for the Quantification of Immunoglobulin G in Bovine Colostrum Powders." Journal of AOAC International 89: 1249-1256.

Elfstrand, L., H. Lindmark-Mansson, et al. (2002). "Immunoglobulins, growth factors and growth hormone in bovine colostrum and the effects of processing." International dairy journal 12(11): 879-887.

Ferreira, I. M. P. L. V. O. (2003). "Quantification of non-protein nitrogen components of infant formulae and follow-up milks: comparison with cows' and human milk." British journal of nutrition 90: 127-133.

Fomon, S. J. (1993). Nutrition of Normal Infants. St. Louis, MO, Mosby.

Fox, P. F. and P. L. H. McSweeney (2003). Advanced Dairy Chemistry - Proteins (Part A), Kluwer Academic / Plenum Publishers.

Gapper, L. W., D. E. J. Copestake, et al. (2007). "Analysis of bovine immunoglobulin G in milk, colostrum and dietary supplements: a review [electronic resource]." Analytical and bioanalytical chemistry 389: 93-109.

Gillies, M. T. (1974). Whey Processing and Utilization, Economic and Technical Aspects. Park Ridge, NJ, Noyes Data Corporation.

Gopal, P. K. and H. S. Gill (2000). "Oligosaccharides and glycoconjugates in bovine milk and colostrum." British journal of nutrition 84(0): 69-74.

Horwitz, W. and J. G. Latimer (2006). Official Methods of Analysis of AOAC International. Gaithersburg, MD, AOAC International.

Indyk, H. E., M. J. Edwards, et al. (1996). "High performance liquid chromatographic analysis of lactose-hydrolysed milk." Food chemistry 57(4): 575-580.

ISEO (2006). Food Fats and Oils, Technical Committee of the Institute of Shortening and Edible Oils.

Jensen, R. G. (1995). Handbook of Milk Composition. San Diego, CA, Academic Press. 
Kehoe, S. I., A. J. Heinrichs, et al. (2007). "A Survey of Bovine Colostrum Composition and Colostrum Management Practices on Pennsylvania Dairy Farms (Erratum: 2008 May, v. 91, no. 5, p. 2164.)." Journal of dairy science 90: 4108-4116.

Kelly, G. S. (2003). "Bovine Colostrums: A Review of Clinical Uses." Alternative Medicine Review 8(4): 378-394.

Kummer, A., D. Kitts, et al. (1992). "Quantification if bovine IgG in milk using enzymelinked immunosprbent assay." Food and Agricultural Immunology 4: 93-102.

Levieux, D. and A. Ollier (1999). "Bovine immunoglobulin G, beta-lactoglobulin, alphalactalbumin and serum albumin in colostrum and milk during the early post partum period." Journal of dairy research 66(3): 421-430.

Li-Chan, E., A. Kummer, et al. (1995). "Stability of bovine immunoglobulins to thermal treatment and processing." Food Research International 28(1): 9-16.

Mahan, K. and S. Escott-Stump (2004). Krause's Food, Nutrition and Diet Therapy. Philadelphia, PA, Saunders / Elsevier.

Martin-Sosa, S., M. J. Martin, et al. (2003). "Sialyloligosaccharides in human and bovine milk and in infant formulas: variations with the progression of lactation." Journal of dairy science 86(1): 52-59.

Martin, M. J., S. Martin-Sosa, et al. (2001). "Distribution of bovine milk sialoglycoconjugates during lactation." Journal of dairy science 84(5): 995-1000.

Martin, M. J., S. Martin-Sosa, et al. (2001). "Bovine milk gangliosides: changes in ceramide moiety with stage of lactation." Lipids 36(3): 291-298.

Martinez-Ferez, A., S. Rudloff, et al. (2006). "Goats' milk as a natural source of lactosederived oligosaccharides: Isolation by membrane technology." International dairy journal 16: 173-181.

Martinez-Ferez, A., S. Rudloff, et al. (2006). "Goats' milk as a natural source of lactosederived oligosaccharides: Isolation by membrane technology." International dairy journal 16(2): 173-181.

Mason, B. S. and H. T. Slover (1971). A gas chromatographic method for the determination of sugars in foods. J Agr Food Chem: 551-554.

McJarrow, P. and J. van Amelsfort-Schoonbeek (2004). "Bovine sialyl oligosaccharides: seasonal variations in their concentrations in milk, and a comparison of the colostrums of Jersey and Friesian cows." International dairy journal 14(7): 571579.

Mehra, R. and P. Kelly (2006). "Milk oligosaccharides: Structural and technological aspects [electronic resource]." International dairy journal 16: 1334-1340.

Mehra, R., P. Marnila, et al. (2006). "Milk immunoglobulins for health promotion." International dairy journal 16(11): 1262-1271.

Nakamura, T., H. Kawase, et al. (2003). "Concentrations of sialyloligosaccharides in bovine colostrum and milk during prepartum and early lactation." Journal of dairy science 86: 1315-1320.

Olivartes, J. and M. Verdys (1988). "Isocratic high performance liquid chromatographic method for studying the metabolism of blood plasma pyrimidine nucleosides and bases." Journal of Chromatography 434. 
Przybylska, J., E. Albera, et al. (2007). "Antioxidants in Bovine Colostrum [electronic resource]." Reproduction in domestic animals 42: 402-409.

Quigley, J. D., R. E. Strohbehn, et al. (2001). "Formulation of colostrum supplements, colostrum repacers and acquisition of passive immunity in neonatal calves." Journal of dairy science 84(9): 2059-2065.

Santschi, D. E., A. K. M. Witschi, et al. (2009). "Colostrum and milk fatty acids of dairy cows as influenced by extruded linseed supplementation during the transition period." Canadian journal of animal science 89(3): 383-392.

Schlimme, E., D. Martin, et al. (2000). "Nucleosides and nucleotides: natural bioactive substances in milk and colostrum." British journal of nutrition 84(suppl.1): s59s68.

Schuster, R. (1988). "Determination of Amino Acids in Biological, Pharmaceutical, Plant, and Food Samples by Automated Precolumn Derivitization and HPLC." Journal of Chromatography 431: 271-284.

Simonne, A. H., E. H. Simonne, et al. (1997). "Could the Dumas method replace the Kjeldahl digestion for nitrogen and crude protein determinations in foods?" Journal of the science of food and agriculture 73(1): 39-45.

Starkey, D. E., J. E. Denison, et al. (2008). "Single-laboratory validation of a liquid chromatographic/tandem mass spectrometric method for the determination of free and total carnitine in infant formula and raw ingredients." Journal of AOAC International 91: 130-142.

Stecher, P. G. (2001). The Merck Index. Rahway, NJ, Merck \& Co.

Tsioulpas, A., A. S. Grandison, et al. (2007). "Changes in Physical Properties of Bovine Milk from the Colostrum Period to Early Lactation." Journal of dairy science 90: 5012-5017.

USFDA (2007). Pasteurized Milk Ordinance 2007, Standards for Grade "A" Pasteurized, Ultra-Pasteurized and Aseptically Processed Milk \& Milk Products. United States of America.

Walstra, P., J. T. M. Wouters, et al. (2006). Dairy Science and Technology. Boca Raton, FL, CRC Press.

Wang, B., J. Brand-Miller, et al. (2001). "Concentration and distribution of sialic acid in human milk and infant formulas." American journal of clinical nutrition 74(4): 510-515.

Webb, B. H., A. H. Johnson, et al. (1974). Fundamentals of Dairy Chemistry. Westport, CT, The AVI Publishing Company, Inc.

Wong, N. P. (1988). Fundamentals of Dairy Chemistry. New York, NY, AVI / Van Nostrand Reinhold.

Woollard, D. C. and H. E. Indyk (1993). "The determination and distribution of taurine in dairy products." Food chemistry 46(4): 429-437.

Woollard, D. C. and H. E. Indyk (2002). "Rapid determination of thiamine, riboflavin, pyridoxine, and niacinamide in infant formulas by liquid chromatography." Journal of AOAC International 85(4): 945-951. 